by Yaoling Niu ${ }^{1,2}$, Marjorie Wilson ${ }^{3}$,Emma R. Humphreys ${ }^{4}$ and Michael J. O'Hara ${ }^{5}$

\title{
A trace element perspective on the source of ocean island basalts (OIB) and fate of subducted ocean crust (SOC) and mantle lithosphere (SML)
}

\author{
1 School of Earth Sciences, Lanzhou University, Lanzhou 730000, China. E-mail: yaoling.niu@foxmail.com \\ 2 Department of Earth Sciences, Durham University, Durham DH1 3LE, UK \\ 3 School of Earth and Environment, The University of Leeds, Leeds LS2 9JT, UK \\ 4 Department of Earth Sciences, University of Bristol, Bristol BS8 1RJ, UK \\ 5 Institute of Geography and Earth Sciences, Aberystwyth University, Aberystwyth SY23 3DB, UK
}

The history of petrogenesis has been the history of re-interpretations of origins - Peter J. Wyllie

We analyze the first-order observations, basic concepts and explicit/implicit assumptions built into the three major hypotheses for the enriched component(s) in the source of ocean island basalts (OIB) in terms of incompatible trace elements: (1) subducted ocean crust (SOC), (2) subducted continental sediments, and (3) mantle metasomatism. SOC is compositionally too depleted (i.e., $[\mathrm{La} / \mathrm{Sm}]_{N}<1$ ) to be the major source material for OIB that are highly incompatible element enriched (e.g., $\left.[\mathrm{La} / \mathrm{Sm}]_{N}>>1\right)$. We cannot rule out the contribution of continental sediments as an enriched OIB source component; however, except for two known cases that are yet to be further investigated, there is no convincing evidence for any significant sediment contribution to the petrogenesis of global OIB. Continental materials through subduction erosion can certainly contribute to mantle compositional heterogeneity and may contribute towards some enriched component in OIB source regions. Overall, OIB are not only enriched in incompatible elements, but also enriched in the progressively more incompatible elements, with their inferred source material being variably more enriched than the primitive mantle. These observations require that the OIB sources are pre-enriched by lowdegree (Low-F) melt metasomatism. The interface between the growing oceanic lithosphere and the top of the seismic low velocity zone (LVZ) represents a natural peridotite solidus and is the ideal site for major low-F melt induced metasomatism. The $\sim 70 \mathrm{Myr}$ history of oceanic lithosphere growth to its full thickness of $\sim 90$ $\mathrm{km}$ records the history of mantle metasomatism, resulting in the deep portion of the oceanic lithosphere being an important enriched geochemical reservoir. We argue that ancient subducted metasomatized mantle lithosphere (SML) provides the major source component for OIB. The metasomatic agent is an $\mathrm{H}_{2} \mathrm{O}-\mathrm{CO}_{2}$-rich silicate melt derived from within the LVZ. Upward migration and concentration of the melt at the lithosphere-LVZ interface (i.e., the lithosphere-asthenosphere boundary or LAB) results in chemical stratification in the LVZ with the deeper portion being more depleted (i.e., DMM), providing the source for MORB. The widespread metasomatized peridotites, pyroxenites and hornblendites from xenolith suites exhumed from the deep lithosphere (both oceanic and continental) and in orogenic peridotite massifs confirm the role of a low-F silicate melt phase as the metasomatic agent. The SOC, if subducted into the lower mantle, will be too dense to return in bulk to the upper mantle source regions of oceanic basalts, and may have contributed to the two large low shear wave velocity provinces (LLSVPS) at the base of the mantle beneath the Pacific and Africa over Earth's history.

\section{Introduction}

Differences in the geochemical characteristics of mid-ocean ridge basalts (MORB) and intra-plate ocean island basalts (OIB) were already obvious over 40 years ago (Gast, 1968). These differences were instrumental in formulating the mantle plume hypothesis (Morgan, 1971, 1972). OIB are rich in potassium and light rare earth elements, which is consistent with a mantle plume origin from a primordial mantle source deep in the lower mantle, whereas the ocean ridge crests tap only the passively rising shallow asthenosphere that has low potassium and light rare earth element contents because of previous seafloor spreading-related episodes of reworking (Morgan, 1972). This first-order perception remains largely unchanged although our understanding of the mantle geochemistry is much better today 
thanks to the efforts of intensive, world-wide sampling and detailed trace element and isotope studies using analytical methods of varying sophistication over the past forty years.

One of the major advances in this regard is the recognition of mantle compositional heterogeneities through studies of oceanic basalts. OIB are particularly variable in composition such that several isotopically distinct mantle source end-members (e.g., "DMM", "EM1", "EM2", "HIMU", "FOZO", "C") have been proposed to explain the variability (e.g., White, 1985; Zindler and Hart, 1986; Hart et al., 1992; Hanan and Graham, 1996; Hofmann, 1997). The isotopic ratio differences among these end-members reflect the differences of the radioactive parent/radiogenic daughter (P/D) ratios (e.g., $\mathrm{Rb} / \mathrm{Sr}, \mathrm{Sm} / \mathrm{Nd}, \mathrm{Lu} / \mathrm{Hf}, \mathrm{U} / \mathrm{Pb}$ and $\mathrm{Th} / \mathrm{Pb}$ ) in their ultimate mantle sources which, with time, evolve to distinctive fields in isotope ratio spaces. Significant fractionation of parent/daughter (P/D) ratios in the solid state is considered unlikely in the deep mantle due to extremely slow diffusion rates (Hofmann and Hart, 1978); hence it is logical to suspect that processes known to occur in the upper mantle and crust (e.g., magmatism, metamorphism, weathering and sedimentary processes) are the likely causes of any P/D fractionation. These shallow or near-surface P/D fractionated materials are then introduced into the mantle sources of oceanic basalts through subduction zones. Mantle compositional heterogeneity is thus assumed to be a general consequence of plate tectonics. Despite this apparent conceptual clarity, our understanding of the origin of mantle compositional heterogeneity, in particular the origin of the enriched geochemical signatures of OIB, remains somewhat incomplete.

Here, we do not attempt to solve the OIB source problem, nor to conduct a comprehensive review of the scientific literature, but to analyze the first-order observations, basic concepts and explicit/ implicit assumptions built into the major hypotheses for the enriched component(s) in OIB sources in terms of incompatible trace elements. While radiogenic isotopes are important in helping revealing OIB source histories as dealt with by many, we take an incompatible element approach in illustrating the concepts because it is, relativelyspeaking, simple, explicit and straightforward relative to that based on radiogenic isotopes; the latter can be quite complex, and their interpretations ultimately rely on an understanding of trace elements, especially the P/D ratios, as discussed above. Willbold and Stracke (2006) have demonstrated that the EMI, EMII and HIMU OIB end-members, defined on the basis of their $\mathrm{Sr}-\mathrm{Nd}-\mathrm{Pb}$ isotope characteristics, cannot be uniquely distinguished in terms of incompatible trace elements. Because of the wide-spread association of "OIB" with "mantle plumes", we hope the conclusions reached in this study may contribute to the great mantle plume debate (e.g. Campbell, 2005; Davies, 2005; Foulger, 2005; Foulger et al., 2005; Niu, 2005; Campbell and Davies, 2006) although the debate cannot be resolved using the geochemistry alone. In order to make the discussion here more effective, we first briefly go over historic and current thinking about OIB mantle source regions and the basic underpinning concepts.

\section{A brief overview}

The primitive mantle (PM) is a hypothetical construct representing the silicate portion of the bulk Earth. Whether any material of this composition still remains within the mantle is conjectural, but it has been implicitly assumed in all models and discussions that the PM was compositionally uniform from its inception upon the core separation in the early Earth. Abundant geochemical evidence indicates that the mantle source of MORB is more depleted, both isotopically and in terms of incompatible element abundances, than the mantle source of OIB. By interpreting MORB-source mantle depletion as resulting from continental crust extraction in Earth's early history (e.g., Armstrong, 1968; Gast, 1968, Hofmann, 1988), we could be satisfied with the OIB source being less depleted than the MORB source. However, the OIB source is actually more enriched in incompatible elements than the PM (Sun and McDonough, 1989; Niu and O'Hara, 2003, 2009; Prytulak and Elliott, 2007; Humphreys and Niu, 2009). It also varies significantly in its inferred abundances and ratios of incompatible elements, as well as radiogenic isotopes, from one island to another and from one group of islands to another group.

By accepting the notion that mantle compositional heterogeneity results from plate tectonics, it is logical to search for the incompatible element enriched OIB component in this context. Hofmann and White (1982) were the first advocates for "Recycled Oceanic Crust" (ROC) as the enriched source material for OIB. They proposed that oceanic crust is returned to the mantle during subduction. Eventually, it becomes unstable (at the core-mantle boundary; see Christensen and Hofmann, 1994) as a consequence of internal heating, and the resulting diapirs become the source of ocean island basalts (OIB) and other hot-spot volcanism. While some details are considered conjectural, the principal idea of the ROC model has been widely accepted as being correct (see White, 2010).

Some authors have suggested that subducted terrigenous sediments (upper continental crust (CC) derived material) may be responsible for enriched signatures of OIB in terms of both incompatible trace elements and isotopes (e.g., Chauvel et al., 1992; White and Duncan, 1996; Hofmann, 1997; Jackson et al., 2007). Others have emphasized the importance of mantle metasomatism (Sun and McDonough, 1989; McKenzie and O'Nions, 1995; Halliday et al., 1995; Niu et al., 1996, 1999, 2002, 2011; Niu and O'Hara, 2003; Donnelly et al., 2004; Workman et al., 2004; Pilet et al., 2005, 2008, 2011; Niu, 2008, 2009; Humphreys and Niu, 2009).

\section{Subducted ocean crust (SOC) is not a major source for OIB}

Niu and O'Hara (2003) showed in terms of straightforward petrology, trace element/isotope geochemistry and mineral physics that ancient subducted ocean crust (SOC) cannot be the major source material for OIB. Among many other reasons, SOC, if subducted to the lower mantle, will not return in bulk to the upper mantle, but will sink irreversibly to the base of the mantle. This is because ocean crust of MORB composition is denser than the ambient mantle at all depths except the depth interval between 660 and $720 \mathrm{~km}$ (Ono et al., 2001; Hirose et al., 2005; also see discussion by Niu and O'Hara, 2003), and it is not straightforward how such dense material can rise in bulk to OIB source regions in the upper mantle. We do not, however, rule out the possible presence of fragments of SOC entrained in some form of deep mantle upwelling. Consequently, it is not surprising if some OIB do indeed contain traces of the geochemical fingerprint of SOC. Note that we need to make a conceptual distinction here between the terms ROC and SOC: SOC is a description, but ROC is an interpretation that SOC is necessarily returned to OIB source regions. 


\section{SOC is too depleted to be the source material for OIB}

If SOC cannot return in bulk to the mantle source regions for OIB, the concept of "recycled oceanic crust" (ROC) as OIB source may not be practical. We can readily demonstrate that the "ROC" interpretation for OIB has difficulties. Figure 1 shows this analysis schematically in terms of rare earth element (REE) patterns. Obviously, melting of incompatible element depleted SOC cannot produce incompatible-element highly enriched OIB (process 4 in Fig 1), without even mentioning the petrologic unlikeness of partially melting basaltic rocks (SOC) with $\mathrm{MgO}<13 \mathrm{wt} \%$ alone to produce picritic melts with $\mathrm{MgO}>15 \mathrm{wt} \%$ (e.g., primitive Hawaiian OIB) (see Niu and O'Hara, 2003). This again simply menas that the major Hawaiian source rock is peridotitic rather than basaltic/eclogitic. Figure 2 compares two independent estimates of average OIB (Sun and McDonough, 1989; Willbold and Strake, 2006) with average N-type MORB (Sun and McDonough, 1989) and the mean composition of the ocean crust (Niu and O'Hara, 2003). It is clear that the ocean crust (or SOC when injected into the mantle) is too depleted in

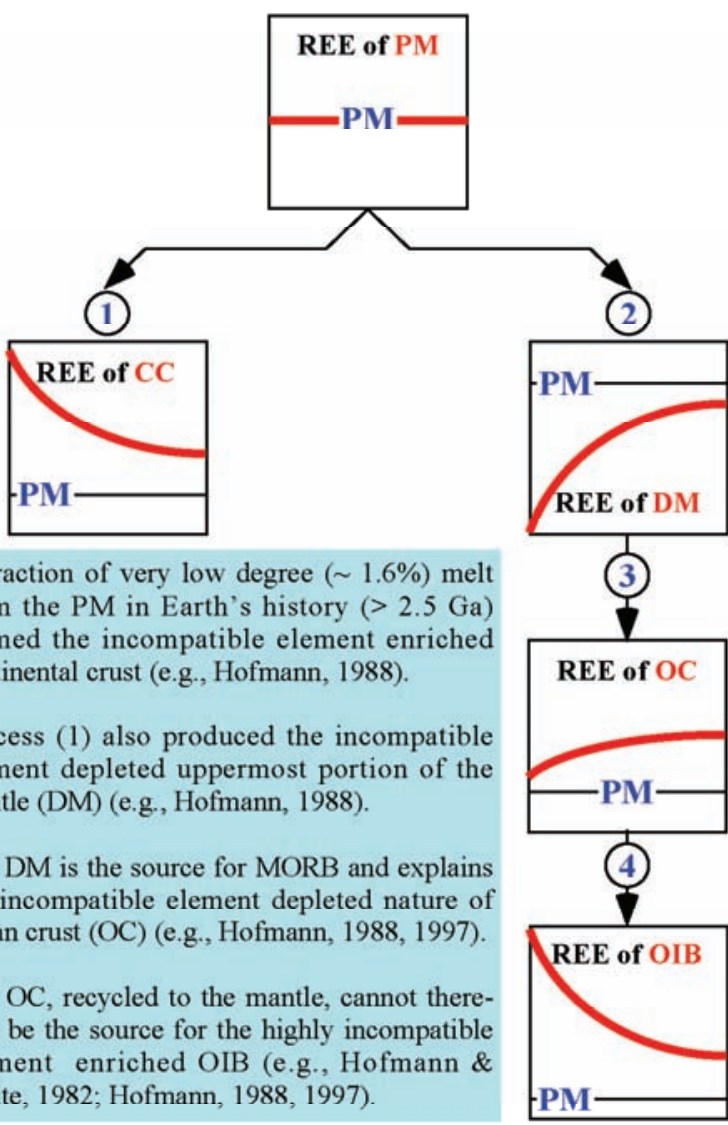

(1) Extraction of very low degree $(\sim 1.6 \%)$ melt from the PM in Earth's history $(>2.5 \mathrm{Ga})$ formed the incompatible element enriched continental crust (e.g., Hofmann, 1988)

(2) Process (1) also produced the incompatible element depleted uppermost portion of the mantle (DM) (e.g., Hofmann, 1988)

(3) The DM is the source for MORB and explain the incompatible element depleted nature of ocean crust (OC) (e.g., Hofmann, 1988, 1997)

(4) The OC, recycled to the mantle, cannot therefore be the source for the highly incompatible element enriched OIB (e.g., Hofmann \& White, 1982; Hofmann, 1988, 1997)

Figure 1 Schematic rare earth element (REE) patterns to illustrate the compositional complementarity between the continental crust (CC) and oceanic crust (OC) following the original work of Hofmann $(1988,1997)$. Note that it is not straightforward how to produce OIB (process 4) that are highly enriched in incompatible elements (e.g., $[\mathrm{La} / \mathrm{Sm}]_{P M} \gg$ 1) by melting subducted OC that is highly depleted in incompatible elements (e.g., $\left.[\mathrm{La} / \mathrm{Sm}]_{P M}<1\right)$, yet "OIB from recycled OC" has remained the most popular model for the petrogenesis of OIB despite the many difficulties of this model. PM refers to the primitive mantle. Modification after Niu (2009).

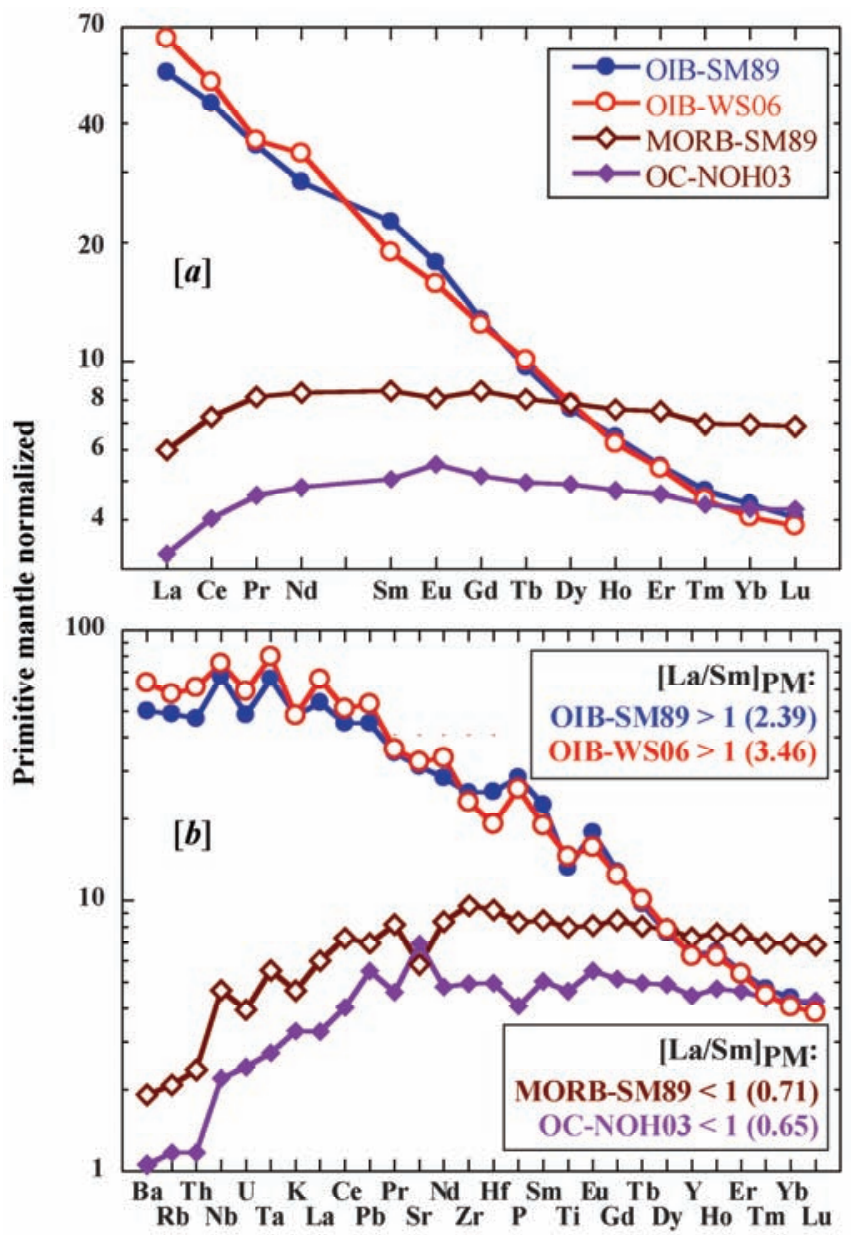

Figure 2 Comparison of average OIB (Sun and McDonough, 1989; Wilbold and Stracke, 2006) with average N-type MORB (Sun and McDonough, 1989) and model ocean crust (OC) (Niu and O'Hara, 2003) in terms of REE [a] and incompatible element abundances [b] normalized to the primitive mantle (PM; Sun and McDonough, 1989). After Niu (2009).

incompatible elements to be a possible source material for OIB, as quantitatively demonstrated in Figure 3 below. Furthermore, even if the ancient SOC were indeed present in the OIB source regions, it is isotopically far too depleted to explain the enriched isotopic properties of OIB (see Figure 1 of Niu and O'Hara, 2003).

Figure 3 demonstrates the argument quantitatively using islandaveraged OIB data (see Table 2 of Humphreys and Niu, 2009 for data source, derived from the global GEOROC database: http:// georoc.mpch-mainz.gwdg.de/georoc/). Since $\mathrm{TiO}_{2}$ (we use $\mathrm{Ti}_{72}$, where 72 refers to the $\mathrm{TiO}_{2}$ content in OIB corrected for fractionation effects to an $\mathrm{Mg}^{\#}$ value of 0.72$)$ and $\mathrm{P}_{2} \mathrm{O}_{5}\left(\mathrm{P}_{72}\right)$ are reliably determined major and minor incompatible element oxides routinely analyzed along with the rest of the major element oxides, and because the REEs are reliable incompatible and moderately incompatible trace elements (vs. other incompatible trace elements in the database; see Humphreys and Niu, 2009 for data discussion), our analysis here is focussed on these elements, i.e., $\mathrm{Ti}_{72}, \mathrm{P}_{72},[\mathrm{La} / \mathrm{Sm}]_{\mathrm{PM}}$ and $[\mathrm{Sm} / \mathrm{Yb}]_{\mathrm{PM}}$. The panels $a, b$ and $c$ on the left in Figure 3 plot $\mathrm{Ti}_{72}, \mathrm{P}_{72}$ and $[\mathrm{La} / \mathrm{Sm}]_{\mathrm{PM}}$ against $[\mathrm{Sm} / \mathrm{Yb}]_{\mathrm{PM}}$. While the data trends (thick grey linear regression lines with arrows) largely point to a control by increasing pressure $(P)$ and decreasing extent $(F)$ of melting from beneath thin lithosphere to 

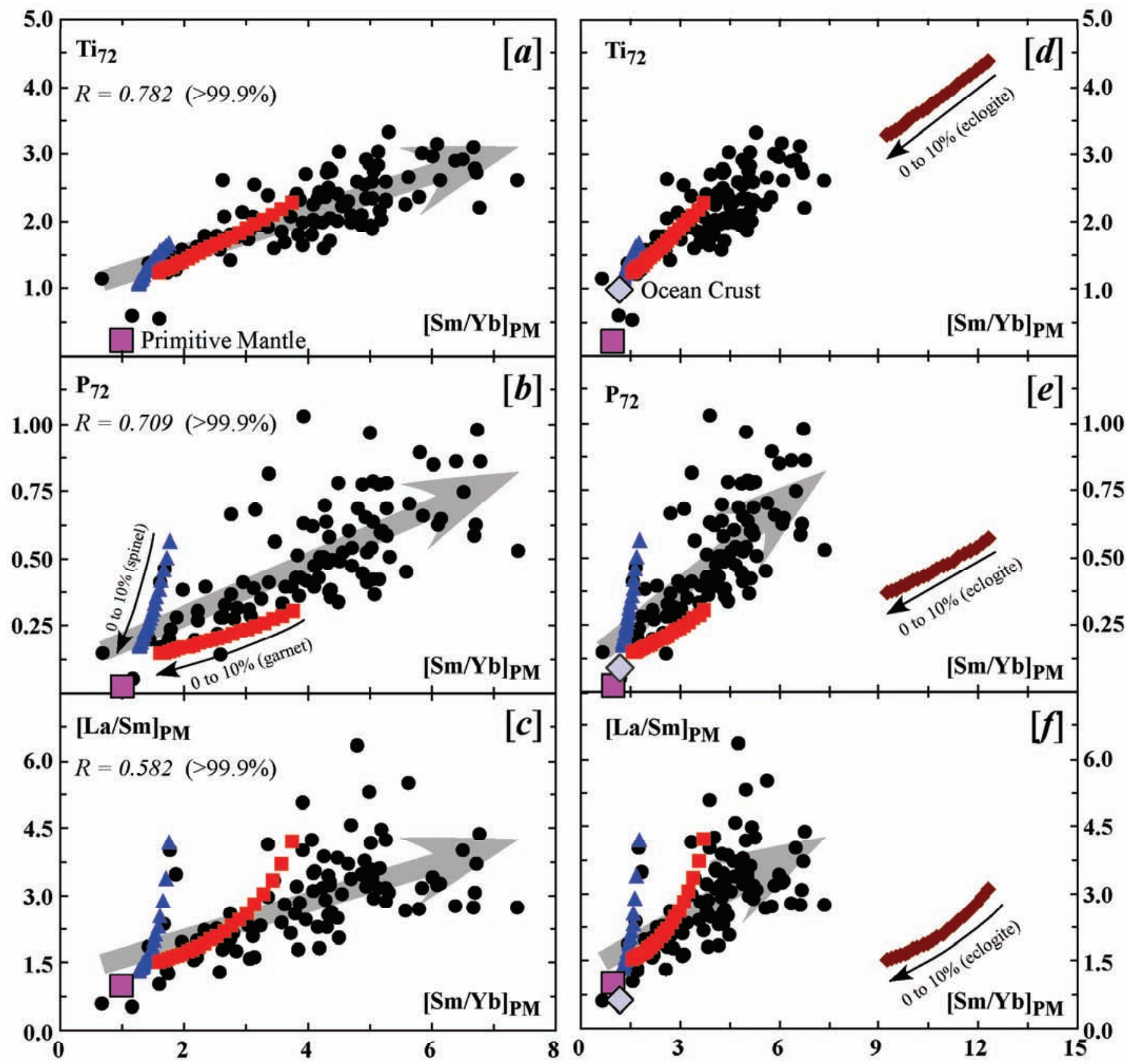

Figure 3 Panels a-c on the left are based on the 115 island-averaged data given in Table 2 of Humphreys and Niu (2009). The thick arrowed lines are regression lines and point in the direction of increasing pressure and decreasing extent of melting with increasing lithosphere thickness (Humphreys and Niu, 2009; Niu et al., 2011). Using the primitive mantle composition (PM, Sun and McDonough, 1989) as the source (purple square) we show that its partial melts by varying extents of partial melting from vanishingly small ( $\sim 0.01 \%)$ to up to $10 \%$ under both garnet (red) and spinel (blue) facies conditions cannot explain the formation of the highly enriched OIB melts. The arrows (downwards and leftwards) in panel b, which applies to all other panels, indicating increasing extent of melting form 0.1 to $10 \%$. The incongruent melting relationship [0.083 olivine $+0.810 \mathrm{cpx}+0.298$ garnet $=0.190$ op $x+1.000$ melt] with initial modes of 0.53 olivine, 0.27 cpx, 0.04 garnet and 0.16 opx (Walter, 1998) is used for garnet peridotite facies melting (red squares). The incongruent melting relationship $[0.652$ op $x+0.466 \mathrm{cpx}+0.049$ spinel $=0.167$ olivine +1.000 Melt $]$ with initial modes of 0.513 olivine, 0.341 opx, 0.131 cpx and 0.015 spinel (Niu, 1997) is used for spinel peridotite facies melting (blue triagles). The simple batch melting model $\left(C_{1} / C_{0}=1 /\left[D_{0}+F(1-P)\right]\right)$ is adequate to illustrate the concept. Relevant partition coefficients are all taken from Prytulak and Elliot (2007). The panels $d-f$ on the right are the same but also show the model bulk composition of the ocean crust (bluish grey diamond; Niu and O'Hara, 2003) and its partial melts (as indicated) by varying extents of melting from vanishingly small $(-0.01 \%)$ to up to $10 \%$ under eclogite facies conditions using modes of 0.6 omphacitic cpx and 0.4 garnet appropriate for MORB protoliths (Song et al., 2006). For conceptual illustration, we did not include rutile and assume modal batch melting with the bulk ocean crust approximates the subducted oceanic crust (SOC) for the elements concerned, these simple calculations allow effective evaluation of the actual roles of SOC in the genesis of OIB melts. Note that inclusion of rutile will lower the $\mathrm{TiO}_{2}$ in the model melt in the $\mathrm{Ti}_{72}-[\mathrm{Sm} / \mathrm{Yb}]_{P M}$ (see text for details). 
beneath thick lithosphere (see Figure 1 of Niu et al. 2011), the large compositional range and the scatter cannot be produced by melting a uniform mantle source. To illustrate the argument, we use the PM composition (Sun and McDonough, 1989) as the source to calculate melt compositions generated by $\sim 0.01 \%$ (vanishingly small) to $10 \%$ batch melting (simple and adequate for this purpose) under both spinel and garnet peridotite facies conditions as indicated (see the caption to Figure 3 for further details). As expected, a variety of sources varying from PM-like to variably much more enriched than PM would be required to explain the OIB compositional spectrum, in particularly, the data with $\mathrm{Ti}_{72}, \mathrm{P}_{72},[\mathrm{La} / \mathrm{Sm}]_{\mathrm{PM}}$ and $[\mathrm{Sm} / \mathrm{Yb}]_{\mathrm{PM}}$ values greater than can be modelled with the extent of melting vanishingly small (Figure 3).

The panels $d, e$ and $f$ on the right in Figure 3 include the bulk ocean crust composition (Niu and O'Hara, 2003) and its partial melts from $~ 0.01$ to $10 \%$ batch melting under eclogite facies conditions (see Figure 3 caption for details). Assuming the bulk ocean crust approximates the SOC composition, these simple calculations suggest that SOC, if present at all in OIB source regions, contributes very little to the enriched OIB compositions. In the $\mathrm{Ti}_{72}-[\mathrm{Sm} / \mathrm{Yb}]_{\mathrm{PM}}$ plot (Figure 3d), it seems possible that SOC melts could represent the enriched end-member for OIB melts. However, such SOC melts cannot contribute in any straightforward way to OIB compositions in the $\mathrm{P}_{72}-[\mathrm{Sm} / \mathrm{Yb}]_{\mathrm{PM}}$ (Figure $3 \mathrm{e}$ ) and $[\mathrm{La} / \mathrm{Sm}]_{\mathrm{PM}^{-}}[\mathrm{Sm} / \mathrm{Yb}]_{\mathrm{PM}}$ (Figure 3f) plots. Furthermore, the proportion of SOC is likely volumetrically small and would be preferentially melted out because of its low solidus temperature and heat-suction effect during melting (Hirschmann and Stolper, 1996; Stolper and Asimow, 2007). As a result, the contribution of SOC by total melting to OIB would be the bulk composition of the SOC itself, which lies at the most depleted end of the OIB compositional spectrum. Therefore, SOC contributes, if not actually diluting, very little to the enriched component of OIB.

\section{Revised "ROC" model has more difficulties}

In recent years, the ROC model has become more popular because of some refreshed lines of evidence (e.g., Sobolev et al., 2000, 2005, 2007). Sobolev et al. (2000) interpreted the composition of olivine melt inclusions in some Hawaiian lavas as recording the signature of "ghost plagioclase" from ancient recycled gabbros (lower ocean crust). This interpretation has gained some acceptance, but as the host olivine of these melt inclusions is a liquidus phase crystallized from cooling and evolving melts in shallow crustal magma chambers, the trapped melt cannot be a primary melt in equilibrium with mantle minerals (Niu and O'Hara, 2003). Thus, it is unclear how the composition of the melt inclusions can be used to infer Hawaiian OIB source lithologies. Furthermore, it is intriguing as to why such a sourceindicating "ghost plagioclase" signature should be preserved only in these minute melt inclusions, yet not in the host lavas. This conundrum was answered elegantly by Danyushevsky et al. (2004), who demonstrated that $\mathrm{Al}-\mathrm{Ca}-\mathrm{Sr}$ rich melt inclusions in phenocryst olivines result from a complex grain-scale dissolution-reaction-mixing process, and that dissolution of phenocryst plagioclase can leave such a signature in the melt inclusions and does not in any way demonstrate a role for recycled gabbros in the petrogenesis of Hawaiian basalts.

Sobolev et al. (2005) argued that the high Ni content of olivine phenocrysts in some Hawaiian lavas reflects the presence of volumetrically significant "SOC" in the mantle source region. The "SOC", in the form of eclogite, melts first to produce $\mathrm{SiO}_{2}$-saturated melts which then react with surrounding harzburgite to produce an olivine-free pyroxenite in the Hawaiian magma source region. The absence of olivine in the resultant source region could explain the high $\mathrm{Ni}$ content in the parental melts and hence the high $\mathrm{Ni}$ contents of the olivine phenocrysts crystallized from $\mathrm{Ni}$-rich basalts in shallowlevel magma chambers beneath Hawaii. Such a conceptually (not necessarily geologically and physically) feasible process was invoked to emphasize the requirement of recycled "SOC" in the petrogenesis of Hawaiian OIB in favour of the "ROC" model. However, it has been demonstrated in terms of straightforward phase equilibria that Hawaiian basalts require olivine to be present in the magma source region (Green and Falloon, 2005; Presnall and Gudfinnson, 2009, 2011). Furthermore, a robust $\mathrm{Ni}$-olivine $\mathrm{Kd}$ and mass balance analysis (Li et al., 2008, Li and Ripley, 2010) has pointed out that the calculations and interpretations by Sobolev et al. (2005) on Hawaiian lavas and olivines are unsupported. More recent experimental studies on $K_{D . N i}$ Olivermelt as a function of $T$ (Wang and Gaetani, 2008; Matzen et al., 2009) demonstrate that the high Ni olivine in Hawaiian melts can be readily produced without having to invoke an olivinefree pyroxenite source. We consider that while an eclogite-derived melt reaction with harzburgite is a petrologically interesting concept, it may actually not take place at all in practice because of the physical difficulty in transporting volumetrically significant amounts of dense eclogite into the source region of Hawaiian magmatism. Importantly, the invoked eclogite of the "SOC" protolith is highly depleted in incompatible elements (Figs. 1 and 2), as is the harzburgite with which the eclogite melt reacts (unless metasomatized; see below). Therefore, this revised ROC (R-ROC) model cannot produce OIB that are highly enriched in incompatible elements (Figs. 2 and 3).

Sobolev et al. (2007) have gone a step further to argue that the $\mathrm{Ni}, \mathrm{Cr}, \mathrm{Mn}$ and $\mathrm{Ca}$ contents of olivine phenocrysts can be used to estimate the proportions of "SOC" in the mantle source regions of basalts erupted both in the ocean basins and on the continents. They showed that olivine Ni contents are high in basalts erupted on thick (> $70 \mathrm{~km}$ ) lithosphere, low in basalts erupted on thin $(<70 \mathrm{~km})$ lithosphere, and lowest in MORB. This, plus the correlated variations of $\mathrm{Cr}, \mathrm{Mn}$ and $\mathrm{Ca}$ in olivine, allowed them to quantify that "SOC" in OIB source regions is necessarily more abundant beneath thick lithosphere than beneath thin lithosphere. They stated that the proportion of "SOC-eclogite" in mantle source regions increases with increasing lithosphere thickness (e.g., $5 \%$ beneath ocean ridges, $10 \%$ in Iceland mantle, and $20 \%$ in Hawaiian mantle). As a result, they proposed that "SOC eclogite induced olivine-free pyroxenite" contributes more to the erupted basalts with increasing lithosphere thickness: 10-20\% for MORB, 20\% for Iceland "OIB", 40\% for Detroit seamount OIB, $\sim 60 \%$ for Hawaiian OIB and $~ 100 \%$ for the Siberian flood basalts.

We have demonstrated that the high quality compositional data provided by Sobolev et al. (2007) for olivines in MORB and basalts erupted both on thin and thick lithosphere in the ocean basins and on the continents are wholly consistent with and readily explained by the variation in the lithospheric thickness or the lid effect (Niu and O'Hara, 2007; Niu et al. 2011) without the need to invoke varying abundances of SOC in the mantle source regions, which has more difficulties. It is intuitively unreasonable that SOC should be more abundant beneath old thick lithosphere than beneath young thin lithosphere. If SOC were passively embedded in a peridotite matrix in the upper mantle, there would be no straightforward physical mechanism that selectively drives the SOC material from beneath 
thin lithosphere to beneath thick lithosphere to be sampled by OIB volcanism. If SOC was incorporated into hot mantle plumes, it is fortuitous that deep-rooted plumes would know the "required" amount of SOC as a function of lithosphere thickness near the Earth's surface. As SOC has a lower melting temperature than the ambient peridotite mantle, it is possible that SOC might contribute more to OIB melts because of the restricted extent of melting beneath thick lithosphere, but SOC is compositionally too depleted to yield highly enriched OIB (Figures.1-3).

\section{Subducted continental sediment is not a major source for OIB}

Many authors have suggested that subducted terrigenous sediments could be responsible for the incompatible element enriched signature of some OIB (see discussion above). In the context of plate tectonics with mantle circulation, it is possible and also likely that terrigenous sediments can be transported into the source regions of oceanic basalts. The question remains as to whether these sediments are indeed the enriched component seen in OIB. Looking at the REE patterns (Figure 4a), the similarity of average OIB (Sun and McDonough, 1989; Wilbold and Strake, 2006) to bulk continental crust (CC; Rudnick and Gao, 2003) and global subducting sediments (GLOSS; Plank and Langmuir et al., 1998) is encouraging, but we can readily see the difficulties when other incompatible trace elements are considered (Figure 4b). The CC and GLOSS have characteristic depletions in $\mathrm{Nb}, \mathrm{Ta}, \mathrm{P}$ and $\mathrm{Ti}$ and enrichment in $\mathrm{Pb}$ - such a "CC-like signature" is rather strong and should be evident in the incompatible element characteristics of OIB if terrigenous sediments were indeed the enriched component. In fact, if anything, OIB are relatively enriched, not depleted, in $\mathrm{Nb}$ (vs. Th) and Ta (vs. U) (Figure 4b; also see Niu and Batiza, 1997).

Thus far, the best evidence for OIB suites with an apparent " $\mathrm{CC}$ like signature" is from the Naturaliste oceanic plateau in the Indian Ocean (Mahoney et al., 1995) and some lava flows from Samoa (Savai) in the Southwest Pacific (Jackson et al., 2007). As the former is geologically close to a passive continental margin with Archean crust whereas the latter is close to the active Tonga subduction zone with a forearc possibly associated with ancient continental lithosphere (Niu et al., 2003), it is unclear if the CC-like signatures in these two cases are indeed produced by recycled terrigenous sediments or continental lithosphere material made available at shallow levels. Further studies of these two cases, based on a combined approach involving petrology, geochemistry, geology and geophysics should prove useful.

In this context, it is necessary to briefly discuss the recent work by Rapp et al. (2008), who conducted ultrahigh pressure (16 to 23 $\mathrm{GPa}$ ) experiments on terrigenous sediments and advocated the significance of their findings in explaining some mantle compositional heterogeneities. They discovered that the stable high- $P$ assemblage contains 15 to $30 \%$ K-hollandite, which controls much of the wholerock budget of large-ion lithophile elements (LILE, e.g., $\mathrm{Rb}, \mathrm{Ba}, \mathrm{Sr}$, $\mathrm{K}, \mathrm{Pb}, \mathrm{La}, \mathrm{Ce}$ and $\mathrm{Th}$ ). They concluded that the incompatible traceelement signature of EMI OIB sources can be attributed to recycling of K-hollandite-bearing continental sediments to Transition Zone depths. We note, however, that the geochemical characteristics of the sediments remain unchanged (Figure 5), and differ distinctly from OIB compositions.

In the context of plate tectonics with sediment subduction (e.g.,

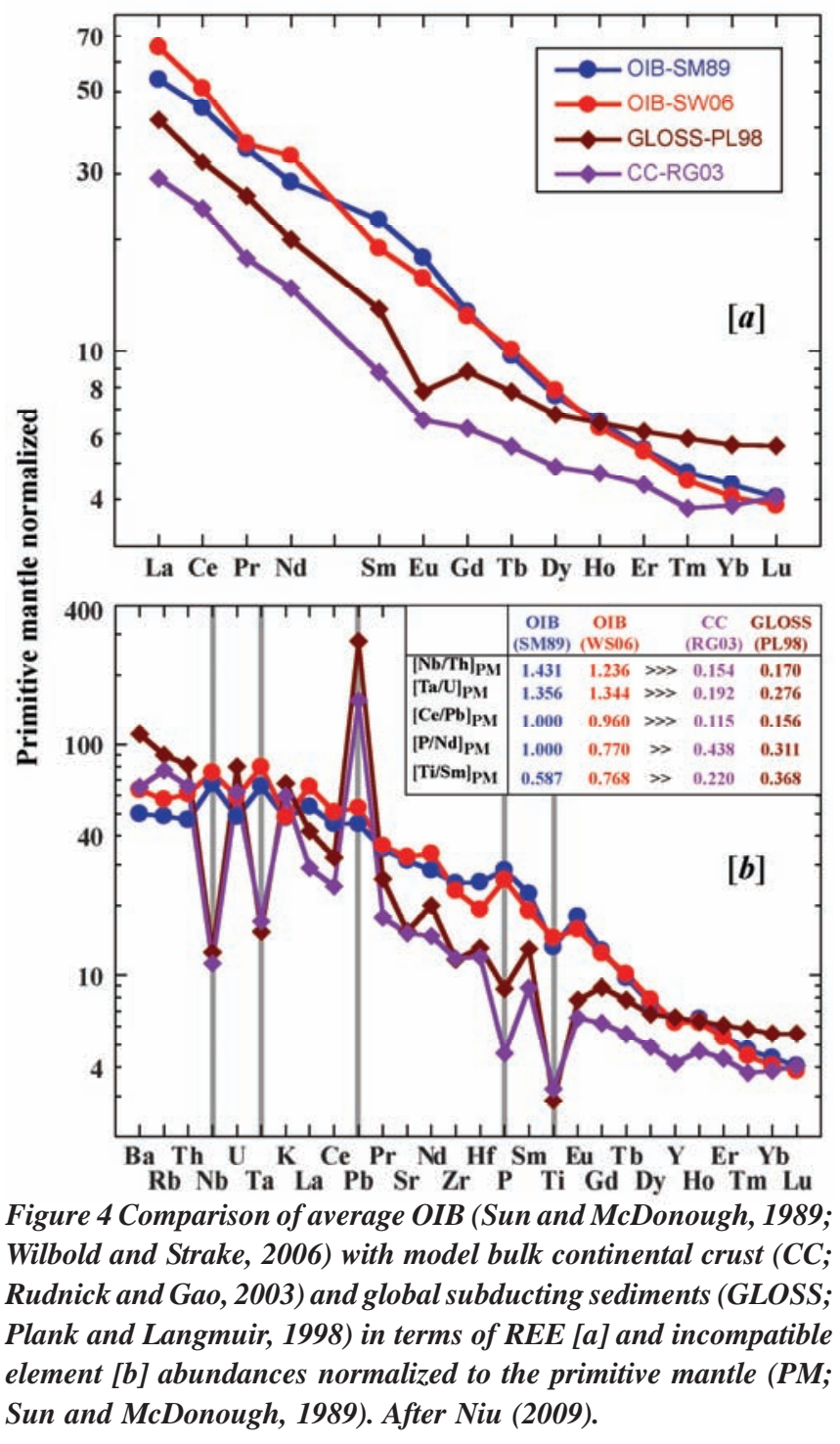

Elliott et al., 1997; Plank and Langmuir, 1998) and subduction zone erosion (von Huene and Scholl, 1991; Clift \& Vannucchi, 2004; Niu and O'Hara, 2009), it is expected that subducted crustal materials can be transported to the source regions of OIB and MORB. It is thus not surprising that signals of CC (and GLOSS) may be detected in the geochemistry of OIB and MORB. However, there is no convincing evidence that recycled CC or GLOSS materials are major contributors to the geochemically enriched signature of global OIB. However, there is the possibility that subducted CC, GLOSS and subductioneroded continental materials may have been diluted in the mantle OIB source regions and thus CC-like signatures (Figure 5) may have been largely "smoothed out" in the mantle. The possibility of the latter scenario needs further investigation.

\section{Continental mantle lithosphere may be a potential enriched source for OIB}

McKenzie and O'Nions (1995) suggested that subcontinental lithospheric mantle (SCLM) could be an important source component for OIB. Because the SCLM is compositionally depleted (in terms of a basaltic component) and therefore physically buoyant, the 


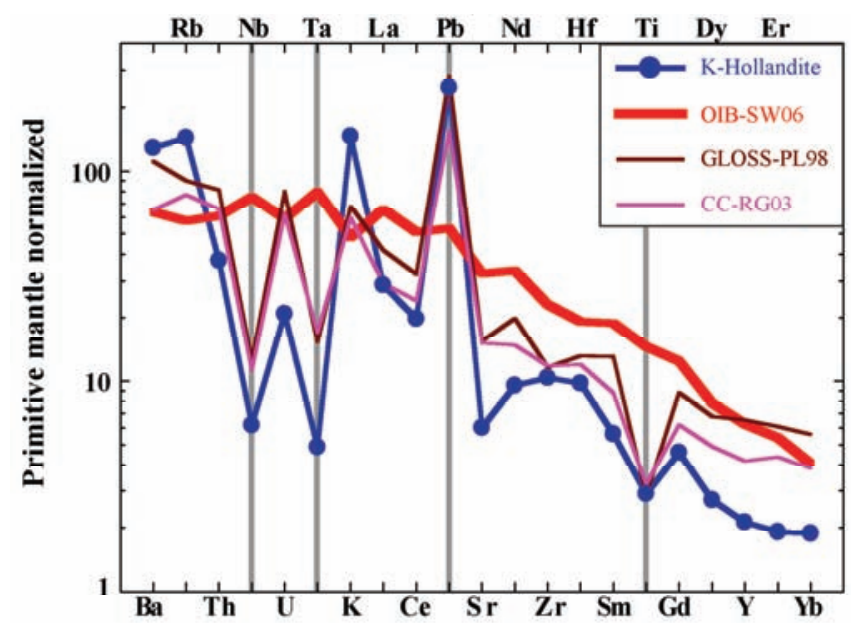

Figure 5 Comparison of the experimental data of Rapp et al. (2008) on terrigenous sediments (i.e., CC-like starting material) under mantle conditions as represented by K-hollandite with actual compositions of CC (Rudnick and Gao, 2003) and GLOSS (Plank and Langmuir, 1998) to show that the ultrahigh-P phase $K$ hollandite is indeed the primary host of the incompatible elements in the bulk rock and retains the trace element signatures of the starting CC-like material. This confirms that subducted sediments compositionally remain unchanged (unless significantly modified in subduction zones) and cannot be the primary enriched source material for OIB and alkali magmas, contrary to the interpretation by the authors. After Niu (2009).

geochemically enriched component in the SCLM, which could be potential OIB source material, must be of metasomatic origin as evidenced by the presence of hydrous minerals (e.g., amphibole, phlogopite) and vein lithologies (e.g., garnet pyroxenite, pyroxenite and hornblendite), present in some mantle xenoliths (Frey and Green, 1974; Frey et al., 1978; Menzies and Murphy, 1980; Menzies, 1983; Menzies and Hawkesworth, 1987; O'Reilly and Griffin, 1988) and massif peridotites (Frey et al., 1985; Takazawa et al., 2000; Pilet et al., 2005). The origin of the metasomatism in the SCLM is poorly understood, but could be conceptually similar to that in the growing oceanic lithosphere (see Niu et al., 1999, 2002; Niu and O'Hara, 2003, 2009; Humphreys and Niu, 2009) as discussed below in detail. We note here that although the seismic low velocity zone (LVZ) is the most likely source of the metasomatic agents (see below), it is poorly defined beneath continents except in locations associated with continental rift systems (e.g., the East African Rift), and in eastern Australia and eastern China where the upper mantle structure resembles that beneath the ocean basins.

The involvement of metasomatized SCLM in intra-plate continental magmatism is physically straightforward, but how metasomatized SCLM materials enter OIB source regions beneath the ocean basins is not. This requires that the metasomatized SCLM becomes part of the convective (asthenospheric) mantle system. SCLM delamination is a widely invoked "process" (see Lorinczi and Housman, 2009), but how such a process actually works remains poorly understood because it is physically difficult for the buoyant SCLM to sink into the denser asthenosphere. Among several conceivable possibilities, "basal hydration-weakening" remains the most effective physical mechanism that can convert "lithospheric mantle" into "asthenospheric mantle" (Niu, 2005, 2006).

\section{Mantle metasomatism of oceanic litho- sphere can explain OIB source enrichment}

\section{Why mantle metasomatism?}

It has been recognized that OIB source materials are enriched in incompatible elements relative to the PM, e.g., $[\mathrm{La} / \mathrm{Sm}]_{\mathrm{OIB} \text { Source }}>$ $[\mathrm{La} / \mathrm{Sm}]_{\mathrm{PM}}$ (e.g., Sun and McDonough, 1989; McKenzie and O'Nions, 1995; Niu et al., 2002; Niu and O'Hara, 2003; Prytulak and Elliott, 2007; Humphreys and Niu, 2009; Figure 3), and that OIB are more enriched in the progressively more incompatible elements (Figure 6). These observations require that OIB sources have undergone prior enrichments through a process of low-degree (low$F$ ) melt infiltration, which is termed mantle metasomatism (e.g., Sun and Hanson, 1975; Lloyd and Bailey, 1975; O'Reilly and Griffin, 1988; Pilet et al., 2005). Wyllie and his collaborators made pioneering contributions to our understanding of mantle metasomatism through experimental petrology and its application to global tectonics and the Earth's chemical differentiation (e.g., Wyllie, 1984, 1985, 1987a,b,c,1988a,b; Wyllie and Huang, 1975,1976; Wyllie and Sekine, 1982; Sekine and Wyllie, 1982a, b; Wyllie et al., 1983; Gaspar and Wyllie, 1987; White and Wyllie, 1992; Baker and Wyllie, 1992; Wyllie and Ryabchikov, 2000).

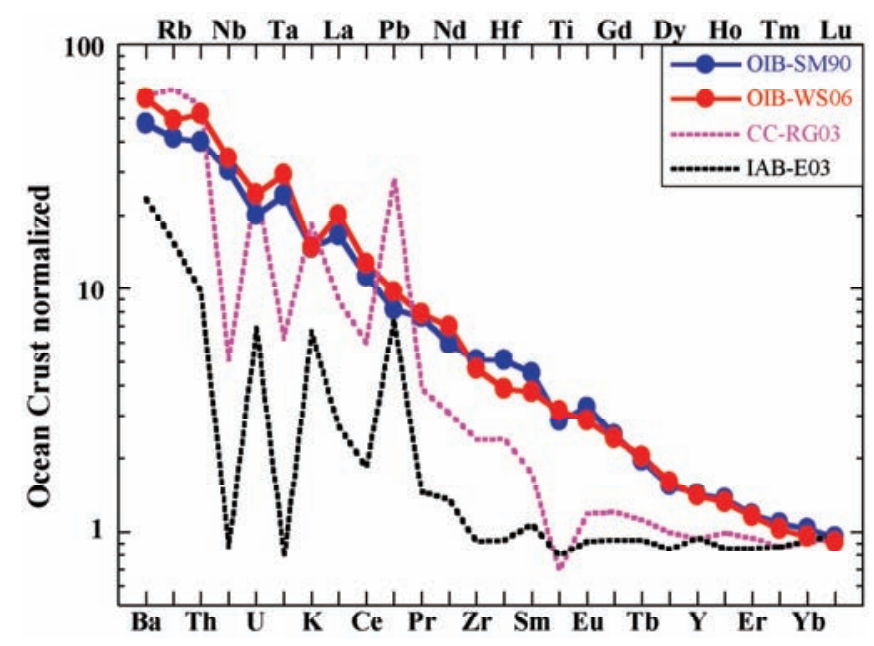

Figure 6 Ocean crust (Niu and O'Hara, 2003) normalized multielement diagram illustrating that $O I B$ are enriched in the progressively more incompatible elements, indicating that the enriched component in OIB is of low-degree melt magmatic origin (i.e., mantle metasomatism). Average OIB compositions are as in Figs. 2 \& 4. For comparison, model compositions of CC (Rudnick and Gao, 2003) and island arc basalts (IAB; Elliott, 2003) are also plotted. After Niu (2009).

The pre-metasomatic sources may be primitive mantle or previously depleted melting residues, and their metasomatism has been ascribed to infiltration by a low- $F$ melts that are enriched in volatiles (e.g., $\mathrm{H}_{2} \mathrm{O}, \mathrm{CO}_{2}$ ) and incompatible elements. The evidence for metasomatism has come from mantle xenoliths in oceanic and continental alkali basalts and kimberlites (e.g., Frey and Green, 1974; Frey et al., 1978; Frey, 1980; Menzies, 1983; Menzies and Hawkesworth, 1987; O'Reilly and Griffin, 1988; Coltorti et al., 1999; Gregoire et al., 2000; Sen et al., 2005; Coltorti and Gregoire, 2008) 
and tectonically exhumed massif peridotites (e.g., Frey et al., 1985; Takazawa et al., 2000) as well as inferences from highly enriched mantle derived melts (e.g., Sun and Hanson, 1975; Lloyd and Bailey, 1975).

\section{Locations of mantle metasomatism}

Wyllie (1980, 1987a, 1988a,b) presented elegant metasomatic models for the petrogenesis of highly enriched magma types such as kimberlite and carbonatite in continental settings and basanite and nephelinite in the ocean basins. He stressed the importance of incipient partial melting in the presence of both $\mathrm{H}_{2} \mathrm{O}$ and $\mathrm{CO}_{2}$ in generating the metasomatic agents which can modify both oceanic and continental lithosphere (e.g. White and Wyllie, 1992; Baker and Wyllie, 1992).

Compared to MORB, OIB samples from all the intra-plate ocean islands so far studied are enriched in incompatible elements with $[\mathrm{La} / \mathrm{Sm}]_{\mathrm{PM}} \gg>1$. Furthermore, many intra-plate seamounts on old ocean crust apparently unrelated to "plumes" or "hotspots" (e.g., Batiza, 1982; Batiza and Vanko, 1984; Castillo et al., 2010), including the very young ( $6 \mathrm{Ma})$ "Petit Spots" alkali basalts erupted on the 135 Ma old Pacific plate (Hirano et al., 2006), are also highly enriched in the incompatible elements.

All these suggest that mantle metasomatism is widespread in the oceanic lithosphere, and is likely also true in the mantle lithosphere beneath continents. In principle, mantle metasomatism cannot take place in regions of major melting such as beneath ocean ridges and in mantle wedges above subduction zones because of high- $F$ (vs. low$F$ ) melting where less enriched or diluted melts prevail. However, because melting regions are finite, low- $F$ melt may exist and metasomatism may thus take place in the peripheral areas of these major melting regions (Niu et al., 1996; Pilet et al., 2011). Mantle wedge overlying subduction zones is surely metasomatized (see Wyllie and Sekine, 1982; Donnelly et al., 2004), but the connection to OIB petrogenesis is obscured because the metasomatic agent there may have an arc-melt signature (i.e., $[\mathrm{Nb} / \mathrm{Th}]_{\mathrm{PM}}(\mathrm{IAB})<1$ and $[\mathrm{Ta} / \mathrm{U}]_{\mathrm{PM}}$ $(\mathrm{IAB})<1)$, whereas both MORB and OIB all have $[\mathrm{Nb} / \mathrm{Th}]_{\mathrm{PM}}$ $(\mathrm{MORB}, \mathrm{OIB}) \geq 1$ and $[\mathrm{Ta} / \mathrm{U}]_{\mathrm{PM}}(\mathrm{MORB}, \mathrm{OIB}) \geq 1$ (Niu and Batiza, 1997; Niu et al., 1999; Niu and O'Hara, 2009; Sun and McDonough, 1989; Halliday et al., 1995; Hofmann, 1997).

The interface between the base of the growing oceanic lithosphere and the seismic low velocity zone (LVZ), which is also termed lithosphere-asthenosphere boundary (LAB), atop the asthenosphere as the ideal site for mantle metasomatism is relevant to OIB petrogenesis (Halliday et al., 1995; Niu et al., 1996, 2002, 2011; Niu and O'Hara, 2003, 2009; Niu, 2008).

\section{Mechanism of mantle metasomatism at the growing oceanic lithosphere-LVZ interface (LAB)}

Figure 7a shows that oceanic lithosphere grows with time through basal accretion of LVZ material (red arrows) before reaching its full thickness after $\sim 70$ million years. The presence of an incipient melt due to the effect of volatiles $\left(\mathrm{H}_{2} \mathrm{O}+\mathrm{CO}_{2}\right)$ in lowering the peridotite solidus is required to explain the characteristics of the LVZ (Lambert and Wyllie, 1968, 1970; Anderson and Spetzler, 1970; Green, 1971, 1991; Wyllie, 1971; Wyllie and Huang, 1975,1976; Green and Liebermann, 1976; Wyllie, 1977; Niu and O'Hara, 2003; Green and Falloon, 2005; Mierdel et al., 2007; Niu, 2008; Green et al., 2010).
This incipient melt is enriched in volatiles (e.g., $\mathrm{H}_{2} \mathrm{O}, \mathrm{CO}_{2}$ ) and incompatible elements (Niu et al., 2002; Niu and O'Hara, 2003). As the melt is buoyant, it tends to concentrate into a "melt-rich layer" (in green) atop the LVZ, leading to compositional stratification within the LVZ. The deep portion of the LVZ (in yellow) is thus depleted (see below). During the process of lithosphere growth, spinel/garnet lherzolite in the uppermost LVZ is thermally captured as newly accreted lithosphere. The low- $F$ melts (from the melt-rich layer) collect and ascend, crystallizing hydrous minerals within the ambient peridotite (modal metasomatism; O'Reilly and Griffin, 1988; Wilshire, 1987; Nielson and Noller, 1987; Harte et al., 1993; Nielson et al., 1993; Nielson and Wilshire, 1993; Pilet et al., 2008, 2011), forming veins of garnet pyroxenite, hornblende-pyroxenite and hornblendite (yellow veins) before being completely absorbed into the ambient peridotite (cryptic metasomatism; O'Reilly and Griffin, 1988; Pilet et al., 2011).

Figure $7 \mathrm{~b}$ presents a parcel of mantle (diapir or "plume") that ascends and partially melts by decompression when it intersects the solidus. As these "plume" melts approach the base of the lithosphere, they may gain additional incompatible element enrichments from the melt-rich layer (green). "Plume" melts ascending further through the lithosphere can assimilate earlier-formed metasomatic veins, leading to further enrichment of the OIB melts that are ultimately erupted (Pilet et al., 2008,2011; Niu, 2008). The erupted OIB melts may thus have three components: (I) fertile mantle source materials from greater depths (plumes?), (II) the LVZ melt layer (green), and (III) components assimilated from the earlier-formed metasomatic vein lithologies in the oceanic lithosphere. Note also that for the petrogenesis of OIB the fertile materials from depth (i.e., component "I") must be volumetrically dominant, compositionally peridotitic, and may contain recycled, previously (ancient) metasomatized, deep portions of oceanic lithosphere that are already enriched in the volatiles and incompatible elements (Niu and O'Hara, 2003). Also, component "I" is required for OIB petrogenesis to explain the basaltic/picritic composition and the first-order coupling between incompatible elements and radiogenic isotopes in many OIB suites (see Niu and O'Hara, 2003; Niu et al., 2011). For example, the highly scattered variation of ${ }^{87} \mathrm{Sr} /{ }^{86} \mathrm{Sr},{ }^{143} \mathrm{Nd} /{ }^{144} \mathrm{Nd},{ }^{206,207,208} \mathrm{~Pb} /{ }^{204} \mathrm{~Pb}$ and ${ }^{176} \mathrm{Hf} /{ }^{177} \mathrm{Hf}$ in average OIB as a function lithosphere thickness (Niu et al., 2011) demonstrates OIB compositional heterogeneity, but also shows weak, yet expected trends reflecting coupling of the isotopic compositions with radioactive parent/radiogenic daughter ratios (P/D; e.g., $\mathrm{Rb} / \mathrm{Sr}$, $\mathrm{Sm} / \mathrm{Nd}, \mathrm{U} / \mathrm{Pb}, \mathrm{Th} / \mathrm{Pb}$ and $\mathrm{Lu} / \mathrm{Hf}$ ). Such coupling requires a time interval between the formation of the metasomatized lithosphere and the volcanism in excess of $1.0 \mathrm{Gyrs}$, which may represent the minimum period from the time of the subduction of ancient oceanic lithosphere into the deep mantle to the return of these materials to the OIB source regions (Niu and O'Hara, 2003). Components "II" and "III" (Figure 7b) are not required for contemporaneous OIB volcanism, but their presence and involvement, if any, can contribute to the petrogenesis of extremely enriched magma compositions such as alkali basalt, basanite and nephelinite on many ocean islands (e.g., Pilet et al., 2008; Niu, 2008) and some intraplate seamounts (e.g., Batiza and Vanko, 1984). If these components were involved, then incompatible elements and radiogenic isotopes would be decoupled because of significant parent-daughter element fractionation by the recent metasomatism (Figure 7), that is too young/recent to produce significant radiogenic isotope ingrowths. The association of incompatible element enrichment with a depleted radiogenic isotopic 


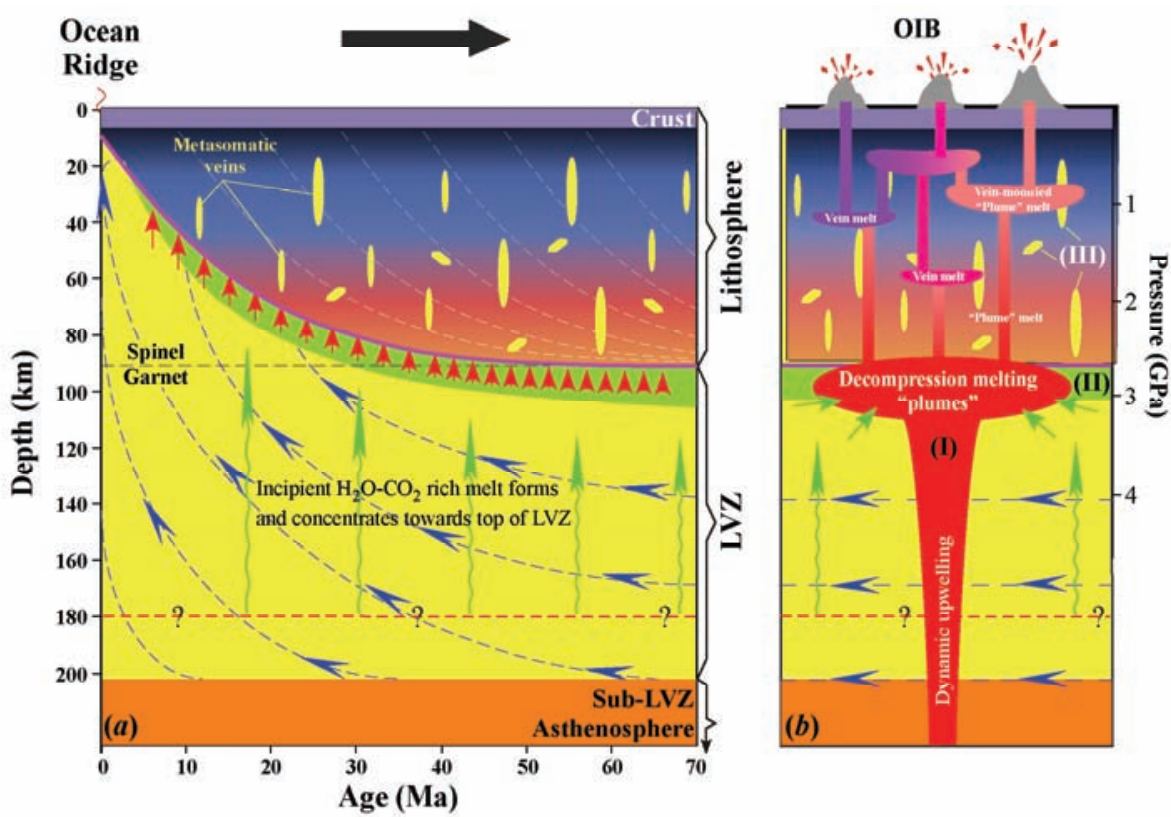

Figure 7 [a] Oceanic lithosphere thickens with time by basal accretion of LVZ material (red arrows) for $\sim 70$ million years before reaching its full thickness of $\sim 90 \mathrm{~km}$ in terms of the plate model. The thick purple curve is the present-day interface $(\mathrm{LAB})$ between the growing lithosphere and the LVZ, which is conceptualized as a natural solidus marking the petrologic transition from solid amphibole/phlogopite-bearing peridotite (lithosphere) to peridotite containing a small melt fraction (LVZ). The thin white dashed curves indicate where this interface was in the past, illustrating the continuing lithosphere growth with time as the plate ages. An incipient melt may form at depth (as deep as $\sim 180 \mathrm{~km}$ ?) in the LVZ caused by the presence of $\mathrm{H}-\mathrm{C}-\mathrm{O}$ volatiles. The incipient melt is thus enriched in these volatiles (e.g., $\mathrm{H}_{2} \mathrm{O}$, $\mathrm{CO}_{2}$ ) and incompatible elements. As the melt is buoyant, it tends to concentrate towards the top of the LVZ as indicated by the green "melt layer" (the thickness is exaggerated for illustration), leading to compositional stratification within the LVZ. The dashed-blue lines with arrows point in the direction of asthenospheric flow because of ridge suction (Niu \& Hekinian, 2004). As a result, MORB samples the more depleted deep portions of the LVZ whereas the enriched "melt layer" atop the LVZ continues to contribute to lithosphere metasomatism before it reaches its full thickness. In the process of the lithosphere thickening, the melt from the "melt layer" will collect and ascend, crystallizing hydrous minerals within the ambient peridotite (i.e., modal metasomatism), forming veins of pyroxenite and hornblendite (yellow veins) before being finally/completely absorbed in the ambient peridotite (i.e., cryptic metasomatism). Because it takes $\sim 70$ million years for the lithosphere to reach its full thickness, metasomatism continues for this length of time. [b] A parcel of mantle material (perhaps a "plume"?) ascends and partially melts by decompression. These "plume" melts (I) may gain additional enrichments from the "melt layer" (II). Continued ascent of the "plume" melts through the lithosphere can cause assimilation of earlier-formed metasomatic veins (III), leading to further enrichment of the ultimately erupted OIB melts. Note that while the "asthenosphere" is often considered synonymous with the LVZ, we here consider the LVZ as the upper portion of the asthenosphere because the latter is present throughout the upper mantle, yet the LVZ is seismically detected mostly beneath ocean basins only. Modified from Niu and O'Hara (2003, 2009) and Humphreys and Niu (2009).

signature is a consequence of recent mantle metasomatism (e.g., Mahoney et al., 1994; Niu et al., 1996).

The occurrence of highly alkaline basalts at off-ridge seamounts on the young (< 3 Ma) seafloor (Batiza, 1982; Batiza and Vanko, 1984; Batiza et al., 1989) suggests that LVZ-related metasomatism is a rapid process. It follows from this and the foregoing discussion that the history of oceanic lithosphere growth through basal accretion in its first $\sim 70$ Myrs records the history of the oceanic mantle lithosphere metasomatism (Niu, 2008). We consider that mantle lithosphere metasomatism is a widespread phenomenon, and the deep portion of the oceanic lithosphere is therefore an important enriched geochemical reservoir (Niu and O’Hara, 2003).

\section{The nature of the metasomatic agents}

The observation that metasomatic vein lithologies (e.g., pyroxenite, hornblendite, other amphibole- and phlogopite-bearing assemblages, as well as grain-boundary enrichment) are common in deep portions of both oceanic and continental lithosphere strongly suggest that the metasomatic agents originate from the seismic LVZ. The observation that OIB are more enriched in the progressively more incompatible elements with respect to major mantle minerals (Figure 6) requires that the metasomatic agents are very low- $F \mathrm{H}_{2} \mathrm{O}$ - and $\mathrm{CO}_{2}$-rich silicate melts. In recent years, carbonatite melt has been a popular choice of metasomatic agent. Wyllie was among the very first to recognize that the presence of $\mathrm{CO}_{2}$ in the $\mathrm{LVZ}$ can induce melting more effectively than $\mathrm{H}_{2} \mathrm{O}$ although he considered that both $\mathrm{CO}_{2}$ and $\mathrm{H}_{2} \mathrm{O}$ must be at work in the LVZ (Wyllie and Huang, 1975, 1976; Wyllie, 1977; Wyllie and Lee, 1998; Wyllie and Ryabchikov, 2000). Several investigators have proposed recently that the LVZ may be largely or perhaps entirely caused by $\mathrm{CO}_{2}$-bearing/generated incipient melts (e.g., Yaxley et al., 1998; Presnall and Gudfinnsson, 2005, 2008; Dasgupta et al., 2007). These arguments are based on the recognition that the solubility of $\mathrm{H}_{2} \mathrm{O}$ in mantle minerals is high enough to absorb any free $\mathrm{H}_{2} \mathrm{O}$ (e.g., Hirth and Kohlstedt, 1995; Karato and Jung, 1998), yet the solubility of $\mathrm{CO}_{2}$ in upper mantle minerals is "diminishingly low" (Keppler et al., 2003). It follows that the free volatile components available in the upper mantle must be $\mathrm{CO}_{2}$ or dominated by $\mathrm{CO}_{2}$ in non supera-subduction zone environments. This naturally leads to the conclusion that $\mathrm{CO}_{2}$-rich melt or carbonatite melt may in fact be the metasomatic agent in the mantle. This argument is further strengthened by the fact that carbonate melts are much more mobile and can readily metasomatize the lithosphere on large scales because of their low viscosity and low solidus temperature.

There is indeed much observational evidence from studies of mantle xenoliths for the importance of carbonatite metasomatism (e.g., Ionov, 1998; Schleicher et al., 1998; Harmer and Gittins, 1998; Coltorti et al., 1999; Gregoire et al., 2000; Newmann et al., 2004). Nevertheless, we consider that $\mathrm{H}_{2} \mathrm{O}-\mathrm{CO}_{2}$-rich silicate melts are far more important as metasomatic agents than carbonatite melt alone 


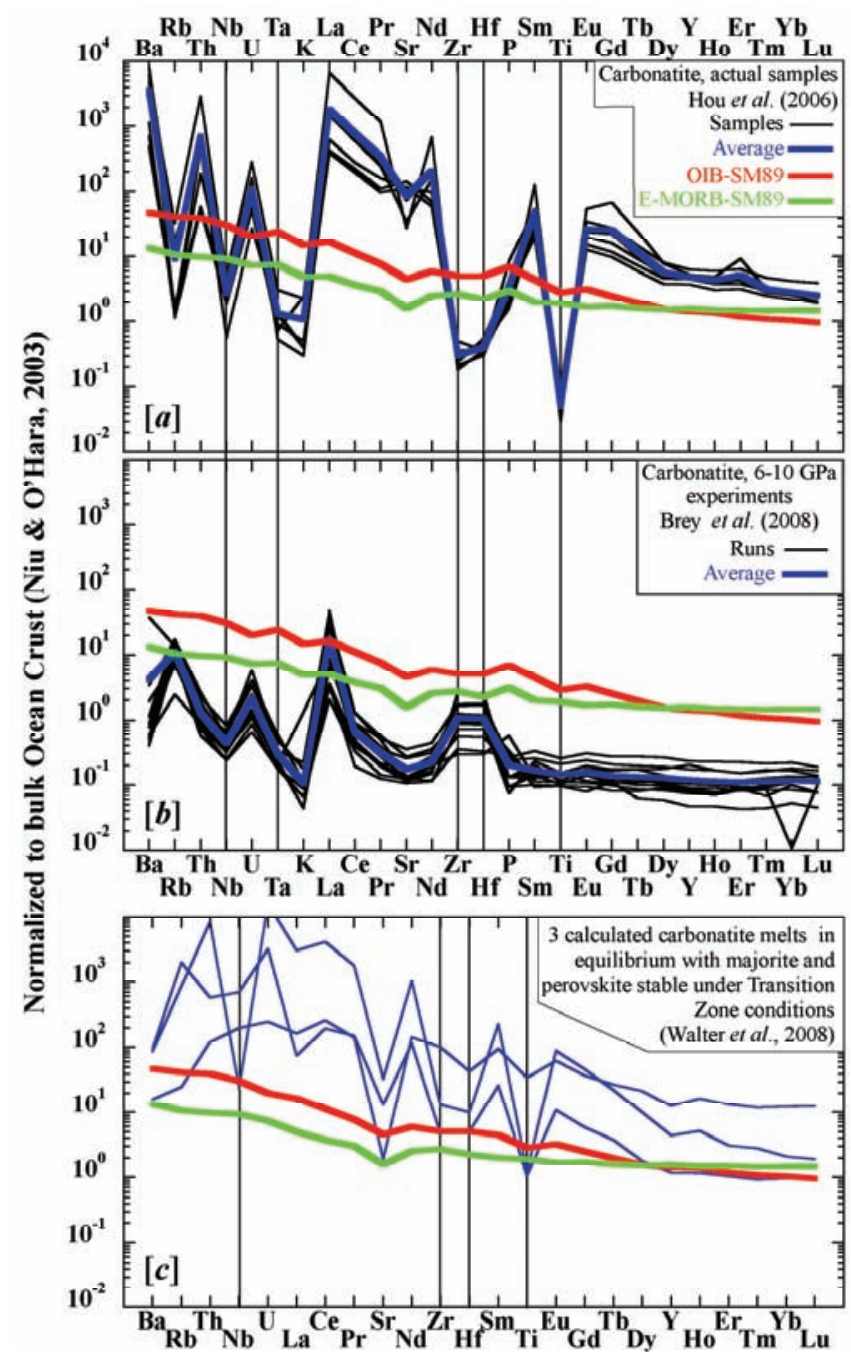

Figure 8 Multi-element diagrams normalized to the average composition of the bulk ocean crust (Niu \& O'Hara, 2003; see Figure 6) to compare representative carbonatites with average OIB. [a] fresh Cenozoic carbonatite melts (dikes/sills without obvious cumulate) from the eastern margin of the Tibetan plateau (Hou et al., 2006) show trace element patterns with REE and LILE enrichment and HFSE depletion (e.g., Baker \& Wyllie, 1992; Hauri et al., 1993). Given such high levels of non-HFSE incompatible elements in carbonatites, if such carbonatite melts were the metasomatic agent for the enriched OIB signature, OIB would inherit such signature, but it is not observed. Also note that such signature is often interpreted as apatite cumulate, but the phosphorous $(P)$ contents in these samples are at the same level as those of OIB. [b] Comparison of carbonatite melts produced experimentally (6-10 GPa) by melting carbonated peridotite (Brey et al., 2008). Note that as they used synthetic starting materials, in order to compare the experimental data with actual rocks like OIB, we removed the effects of starting material composition by normalizing their starting compositions to the primitive mantle (PM; Sun \& McDonough, 1989) with compositions of the run products normalized accordingly. The adjusted abundance levels are lower than expected for OIB, which means that melting of PM composition cannot produce the required enrichments in OIB. By assuming that carbonatites are derived from much more enriched source than the PM, the melts will be enriched, but the elemental for several reasons. (1) Most metasomatic lithologies so far documented from the continental and oceanic lithosphere are dominated by pyroxenite and hornblendite veins (plus garnet, phlogopite, rutile, zircon, titanite), with or without minor carbonate. (2) OIB are enriched in the progressively more incompatible elements, which is consistent with the metasomatic agent being a low- $F \mathrm{H}_{2} \mathrm{O}-$ $\mathrm{CO}_{2}$-rich silicate melt, rather than a carbonatite melt. Natural carbonatites have trace element systematics that are distinct from those of OIB (Figure 8a). High pressure experimental simulation demonstrates that behaviours of incompatible elements in carbonatite melts differ remarkably from their behaviours in OIB (Figure 8b). Carbonatite melts of deep transition-zone origin also show distinct incompatible trace element systematics (Figure 8c).

Therefore, $\mathrm{H}_{2} \mathrm{O}-\mathrm{CO}_{2}$-rich silicate melt, not carbonatite melt, is likely the major metasomatic agent for the petrogenesis of OIB even though carbonatite melt may be locally important, particularly in the continental settings.

\section{Some new insights on mantle dynamics}

The above discussion of OIB sources offers some new insights into a number of fundamental aspects of mantle geodynamics.

\section{A new view on the origin and nature of the depleted MORB mantle}

The current paradigm of solid earth geochemistry is that the upper mantle is depleted in incompatible elements (e.g., Hofmann, 1997), and is therefore termed depleted mantle (DM) or depleted MORB mantle (DMM) (Zindler and Hart, 1986; see Figure 1). The logic behind this is reasonable because MORB are depleted in incompatible elements and the MORB source must therefore be depleted. Because MORB are produced by decompression melting of passive (vs. dynamic) upwelling asthenosphere, the maximum depth of melting must be shallow. Therefore, the DM or DMM reservoir must also be shallow and may occupy the entire upper mantle or upper mantle plus the upper part of the lower mantle (see Donnelly et al., 2004; Workman and Hart, 2005; Niu and O'Hara, 2009). The requirement for the DMM to produce highly incompatible element enriched, near solidus (low- $F$ ) melts that metasomatize the base of the overlying oceanic lithosphere may therefore seem contradictory. This apparent contradiction does not negate the MORB source being depleted, but rather suggests that the standard concept for the DM or DMM (see Figure 1) needs some revision as pointed out by Niu and O'Hara (2009). In Figure 7, the blue dashed lines with arrows point in the

patterns do not favour such carbonatite melt as a metasomatic agent for the enriched signature of OIB. Also, the experimental data show $\mathrm{Nb}$ and Ta depletion, but no Ti depletion, yet $\mathrm{Zr}$-Hf enrichment. [c] 3 calculated carbonatite melts in equilibrium with majorite and perovskite (diamond inclusions) under Transition Zone conditions (Walter et al., 2008). Carbonatites with such trace element systematics may indeed exist in deep parts of the upper mantle or Transition Zone, but if these were metasomatic agents, they would impart such signatures to OIB, but this is again not observed. Therefore, these three cases suggest that even though carbonatitic melts may indeed exist and may be an important metasomatic agent in some mantle environments, they cannot be the major metasomatic agent required for the enriched signature of the global OIB. 
direction of the asthenospheric flow required to feed the ocean ridge because of ridge suction (Niu \& Hekinian, 2004). As a result, MORB sample the deep portions of the LVZ (in yellow) that are already depleted by the removal of a low- $F$ melt. This concept offers an entirely new perspective on the origin and nature of the depleted mantle (Niu and O'Hara, 2009).

In summary, the compositional stratification in the LVZ (Figure 7) is required by the observations: (1) the LVZ is most consistent with the presence of a volatile-rich melt phase; (2) a melt-rich layer atop the LVZ (green) is required by the occurrence of metasomatism at the base of the growing oceanic lithosphere, which is also required by the abrupt seismic velocity drop at the lithosphere-LVZ boundary (or LAB; Kawakatsu et al., 2009; see Niu et al., 2011 for discussion); and (3) ridge-ward asthenosphere flow resulting from ridge-suction (Niu \& Hekinian, 2004) to feed MORB requires that the deep portion of the LVZ is compositionally depleted , i.e., the DMM source.

\section{Fate of subducted oceanic crust}

We have demonstrated above that SOC cannot be the major source for OIB. The question then is what may have happened to SOC in the context of plate tectonics and mantle circulation over Earth's history. If ocean crust of MORB composition can indeed sink to the lower mantle as illustrated by global seismic tomography studies (e.g., van der Hilst et al., 1997; Grand et al., 1997; Karason and van der Hilst, 2000), subducted ocean crust (SOC) will not return in bulk to the upper mantle source regions of oceanic basalts because it is denser than the ambient mantle at all depths except the depth interval between 660 and 720 km (see Ono et al., 2001; Niu and O'Hara, 2003; Hirose et al., 2005). If this irreversible process is indeed the case, then this has profound implications for the chemical structure of the mantle as discussed by Niu and O'Hara (2003):

"As discussed above ... ... oceanic crust subducted into the lower mantle will not return in bulk to the upper mantle because of the negative buoyancy in both solid and liquid states. Transfer of basaltic crust to the lower mantle would be an irreversible process. This supports the argument for a hidden component deep in the lower mantle that has not been sampled by known volcanism ....... and would also lead to chemical stratification of the mantle with the mean composition of the lower mantle becoming progressively enriched in residual ocean crust lithologies (i.e., compositionally lower in $\mathrm{Ca} / \mathrm{Al}$, and higher in $\mathrm{Fe} / \mathrm{Mg}$, Si/ $\mathrm{Mg}, \mathrm{Al}$, and water insoluble incompatible elements such as $\mathrm{Ti}, \mathrm{Nb}, \mathrm{Ta}, \mathrm{Zr}$, and $\mathrm{Hf}$ ). If subduction of oceanic crusts into the lower mantle has continued for some time, then a large compositional contrast in terms of these elements must exist between the upper and lower mantle."

We can conduct a simple exercise following this argument. By assuming that (1) plate tectonics began at $\sim 4.0 \mathrm{Ga}$ (unknown; see Stern, 2007), (2) the oldest ocean crust may not be older than 200 Myrs before subduction as is the case at present, (3) oceanic crust has always occupied $65 \%$ of the Earth's surface area (vs. 35\% area for the continental crust), (4) the average thickness of the ocean crust is about $6 \mathrm{~km}$ with a mean density of $3.0 \mathrm{~g} \mathrm{~cm}^{-3}$ (vs. $3.3 \mathrm{~g} \mathrm{~cm}^{-3}$ for the mantle), then the amount of SOC since $4.0 \mathrm{Ga}$ would be $\sim 3.0 \mathrm{wt} \%$ of the entire mantle. That is, there is $4 \mathrm{Gyrs} / 200 \mathrm{Myrs}=20$ times the present-day ocean crustal mass stored in the deep mantle. This calculation, based on reasonable and explicit assumptions, is clearly only illustrative. We note that there have been several alternative estimates involving more complex assumptions that give variably greater values. For example, Helffrich \& Wood (2001) estimated that $\sim 5 \mathrm{wt} \%$ SOC is randomly distributed throughout the mantle.

\section{Is there any evidence for the SOC accumulated in the deep lower mantle?}

We suggest that the two large low shear wave velocity provinces (LLSVPs) in the lowermost mantle beneath the Pacific and Africa may represent the SOC accumulated over Earth's history. These two large LLSVPs have been recognized for some time (e.g., Dziewonski, 1984; Grand et al., 1997; Su and Dziewonski, 1997; Ritsema et al., 1999; Kellogg et al., 1999; Mégnin and Romanowicz, 2000). They have been interpreted to be excessively hot mantle domains representing the locations of "superplumes" (e.g., Romanowicz and Gung, 2002; Ni et al., 2002), and to be responsible for the geographically associated surface geoid highs or "superswells" (McNutt, 1988) and probably also mantle isotopic anomalies revealed from volcanism on these highs and their peripheral regions (e.g., Hart, 1984; Castillo, 1988). Recent studies suggest that the LLSVPs have sharp boundaries with, and higher density $(\sim 2-5 \%)$ than, the ambient mantle, indicating that they are chemically distinct from the surrounding mantle (Ni et al., 2002; Becker and Boschi, 2002; Ni and Helmberger, 2003; Wang and Wen, 2004; Toh et al., 2005; Ford et al., 2006; Garnero et al., 2007). Their origin is not well understood and their geodynamic effects cannot yet be properly modelled (e.g., McNamara and Zhong, 2004; Lassak et al., 2010). They could be residual Fe-rich material from core formation or subducted ocean crust (e.g., Garnero et al., 2007; Hirose and Lay, 2008).

Our estimate of $\sim 3 \mathrm{wt} \%$ SOC in the entire mantle that at present has accumulated over the course of geological time is similar to the estimated mass of the LLSVPs, $\sim 2 \mathrm{wt} \%$ of the mantle, by Burke et al. (2008). Given the likely uncertainties in these estimates we do not wish to overstate the significance of the calculations, but they do offer an independent line of reasoning in support of the concept that mantle plumes do note originate from recycled oceanic crust and that subducted ocean crust is too dense to return in bulk to the upper mantle source regions of oceanic basalts (Niu and O'Hara, 2003).

\section{The "buoyant" superswells overlie the dense LLSVPS - a contradiction or natural consequence?}

The geoid highs, superswells, and reduced seismic velocity in the lower mantle are all consistent with mantle "superplumes" initiated close to the CMB or lower mantle beneath the Pacific and Africa. However, because the LLSVPs at the base of the mantle beneath these two regions are not buoyant, but rather dense ( 2-5\% denser than the ambient mantle), it is difficult to see how they could be the source of the "superplumes". This apparent contradiction points to a serious physical problem - how could this relationship be possible in terms of straightforward physics? Models that apply an imposed plate history can result in focusing of the subducted materials into piles at the core-mantle boundary beneath Africa and the Pacific, corresponding to the two LLSVPs (e.g., Garnero et al., 2007). These models can explain the location of the two LLSVPs, but still cannot explain the observation that the "massive upwellings" manifested by the superswells are underlain by regions of dense materials of huge 
negative buoyancy. The "superplume" models suggest that the negative buoyancy of the dense materials can be overcome by thermal buoyancy (cf. Garnero et al., 2007), thus leading to the upwelling of the "superplumes". Yet, it seems unlikely that thermal buoyancy can be sufficient to overcome the $>2 \%$ density contrast (Niu and Batiza, $1991 b, c)$, especially because of the very low thermal expansion coefficients at the deep lower mantle conditions (Birch, 1952; Anderson, 2007).

Here we suggest that the existence of buoyant superswells overlaying the dense LLSVPs is not a contradiction, but a natural consequence in terms of plate tectonics, petrology and mineral physics. Transformation of the basaltic ocean crust (MORB + gabbroic cumulates) into eclogite during subduction and further high pressure phase transformation at the $410 \mathrm{~km}$ seismic discontinuity facilitate subduction. Subducting oceanic lithosphere (or slab) can penetrate the $660 \mathrm{~km}$ discontinuity (with some difficulty; see van der Hilst et al., 1997) and enter the lower mantle, sinking eventually to the coremantle boundary region.

Figure 9 shows that under lower mantle conditions, ocean crust with MORB composition is significantly denser $(\sim 3.6 \%)$ than the ambient mantle (PREM), and will tend to sink. By contrast, the mantle lithosphere portion must be less dense than the ambient mantle (PREM) because it contains: (1) a thick section $(<30$ to $60 \mathrm{~km})$ of MORB melting residues beneath the crust that are less dense, (2) water because of incomplete subduction-dehydration (Niu, 2004), which is hosted in serpentine before subduction (developed near ridges and the trench-outer rise), in DHMS phases during subduction, in perovskite in the lower mantle, in ringwoodite/wadsleyite in the

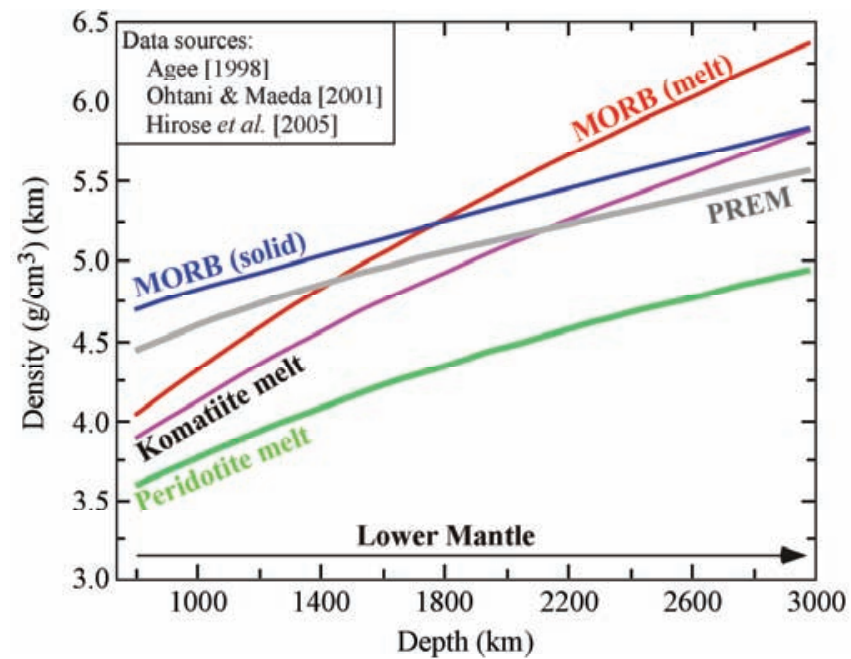

Figure 9 Densities of various Earth materials as a function of depth, simplified from Niu \& O'Hara (2003) based on the experimental data of Agee (1998), Ohtani \& Maeda (2001) and the more recent density data for MORB (solid) by Hirose et al. (2005) to show that under lower mantle conditions, subducted ocean crust of MORB composition [MORB (solid)] is significantly denser ( 3.6\%) than the ambient mantle represented by PREM (Dziewonski \& Anderson, 1981). In the molten state, especially at deep lower mantle conditions, molten ocean crust [MORB (melt)] is denser than komatiite melt (by $\sim 8.6 \%$ ), and even denser than the ambient mantle (by $\sim 13 \%$ ). Importantly, peridotite melt under lower mantle conditions has the lowest density; it is $\sim 12 \%$ less dense than the ambient mantle, and is $\sim 17 \%$ less dense than the solid ocean crust [MORB (solid)].
Transition Zone, and in olivine in the upper mantle (or a vapour phase, causing incipient melting), which reduces both the bulk-rock density and the elastic moduli (e.g., Frost, 1999; Litasov et al., 2003; Mao et al., 2008a.b; Ye et al., 2009; Li et al., 2009; Jacobsen et al., 2008), and (3) refertilized volatile-rich deep portions of the oceanic lithosphere (Figure 7). This means that the subducted lithosphere slab will likely separate into the dense crust (SOC) that sinks to the base of the mantle to form the LLSVPs and the buoyant mantle lithosphere of the slab (SML) that remains at shallower mantle depths. It is thus possible that the dense LLSVPs (SOC) could be overlain by such buoyant subducted mantle lithosphere (SML; Figure 10). Because the SML is $\sim 15$ times the mass of the SOC, it can occupy much of the lower and perhaps part of the upper mantle, and because it is buoyant relative to the ambient mantle (e.g., PREM), it will result in a surface manifestation - the geoid high and superswell in the Pacific and the "poorly-understood high elevation" of the African continent.

\section{Why do LIP eruption sites correspond to edges of the LLSVPs?}

Burke and Torsvik (2004) found that 24 active hotspot volcanoes can be projected to the DVs $=-1 \%$ contours along the edges of the LLSVPs (also see Thorne et al., 2004; Garnero et al., 2007). Burke et al. (2008) further showed that all LIP (large igneous province) eruption sites with ages $<300 \mathrm{Ma}$ lie above the DVs $=-1 \%$ contours at the LLSVP edges, which they called plume generation zones (PGZs), suggesting that the LLSVPs may have remained unchanged for at least the past $300 \mathrm{Ma}$. The latter is expected if the LLSVPs are indeed piles of SOC because (1) ocean crust of MORB composition is much denser than the ambient materials at the base of the mantle in both solid state and liquid form (see Figure 9; also Figure 7 of Niu and O'Hara, 2003), and (2) if our calculations are reasonable, then at $300 \mathrm{Ma}$, the LLSVPs would already have $\sim 92.5 \%$ of their present mass/volume. Localized ultra-low velocity zones (ULVZ) beneath, or in the vicinity of, the LLSVPs just above the CMB (e.g., Garnero et al., 1998; Williams et al., 1998) may be localized melt layers within the SOC induced by core heating. Such melt would be too dense to rise (Figure 9).

It is puzzling why LIP eruption sites should correspond to the edges (vs. centres/interiors) of the LLSVPs. Burke et al. (2008) speculated that "hot material that has been heated by conduction from the core in the basal part of the slab graveyard may be driven toward the PGZs (i.e., the edges of the LLSVPs) by slabs or slab fragments acting like push brooms." Our explanation is much simpler as shown in Figure 10. At the edge of the LLSVPs, which act as thermal insulators, the subducted mantle part of the lithosphere (SML) loses its negative buoyancy by heating from the core and rises. Water may facilitate partial melting in this hot setting, and because peridotite melt is $\sim 12 \%$ less dense than the ambient mantle (e.g., PREM, see Figure 9), this partially molten peridotitic system will readily rise as diapirs (or initial "plumes" if one prefers to call so), explaining why major hotspot volcanoes and LIP eruption sites correspond to the edges (vs. the interiors) of the LLSVPs. Some "small" volcanoes do occur on the topographic highs or swells, for which our interpretation is given in Figure 10 (represented by "g").

If the above diapirs are indeed the source for OIB, then, as we have argued above, the OIB source materials are likely peridotitic in composition and could include the recycled deep portions of ancient 


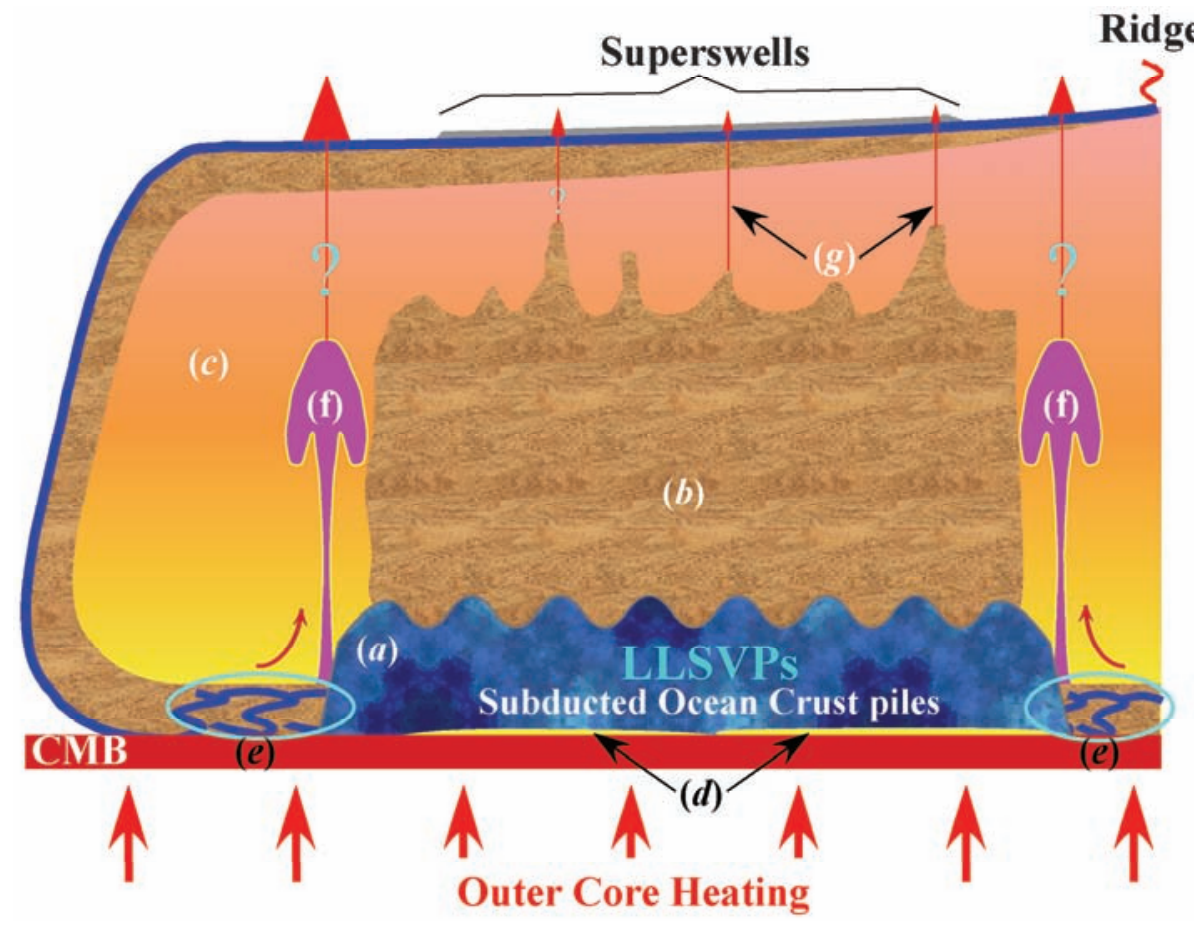

Figure 10 Cartoon (not to scale, excluding complications due to phase changes etc.) to illustrate our explanations for some perplexing features observed seismically (in the deep mantle) and geologically (at the surface) in terms of some familiar geological concepts. [a], the LLSVPs, which are made up of piles of subducted ocean crust (SOC) - the permanent 'graveyard' of subducted ocean crust. They also act as a thermal "insulator", preventing effective core-to-mantle heat transfer. [b], accumulated piles of subducted mantle lithosphere (SML), that is less dense than and separated from the dense [a]. [c], "normal mantle" like "PREM". [d], ultra-low velocity zone (ULVZ) represented by highly localized melt layers/pockets of highest density (Figure 7). [e], edge regions of the LLSVPS at the CMB, where hot diapirs [f] of SML develop and rise. The hot diapirs may contain a peridotitic melt phase, and their ascent is driven by compositional (vs. thermal) buoyancy. They may feed volumetrically significant surface volcanism. [g], possible compositional diapirs originating from SML at shallow depths that may also feed some surface volcanism. Note the mean density relationships among these different constituents at a comparable depth: $[d]>[a]>[c]>[b]>[g] »[f]$ (see Figure 7$)$. Note that the lower density of $[b]$ than [c] is largely due to compositional buoyancy contrast. The subducted mantle lithosphere [b] contains (i) MORB melting residue, which is less dense, (ii) water probably hosted in DHMS phases (dense hydrous magnesium silicates) derived from incompletely subductiondehydrated serpentine beneath the crust developed near ocean ridges, (iii) serpentine developed in the deep lithosphere at the trench-outer-rise, and (iv) refertilized volatile rich deep portions of the lithosphere (see Figure 7). Water can reduce both density and elastic moduli. Consequently, the surface "superswells" are caused by the "density deficiency" of [b], which is not in contradiction to the dense [a]. The thermal insulation of [a] makes [b] not thermally buoyant, but at the edges of [a] the materials of the SML can be heated up and melt. The compositional buoyancy of the SML and its melt facilitates the development of diapirs and their ascent as "plumes". This explains why sites of major volcanoes and LIPs are associated with the edges, not the interiors of, the LLSVPs. Note also that the OIB source materials are NOT [a] (or SOC) that is permanently left at the base of the mantle, but SML of peridotite compositions for logical and petrological reasons discussed in the text (also see Niu \& O'Hara, 2003). In this cartoon, we show for simplicity that disintegration (crust-mantle lithosphere separation) of the subducted slabs may take place at the CMB, but this is not required and the separation can happen at any depths in the lower mantle with the dense crust sinking, adding to the LLSVPs at the base of the mantle and the compositionally buoyant mantle lithosphere in the mid mantle, which can also develop into "chemical plumes". oceanic lithosphere of metasomatic origin (i.e., SML or portions of SML; see Figure 7). The SOC is likely forever stored at the base of the mantle so long as the plate tectonics continues, even though we do not rule out the possibility that volumetrically insignificant fragments of the SOC could be incorporated in the rising diapirs.

\section{Summary}

1 The geochemically enriched trace element signatures of OIB are largely inherited from their enriched fertile mantle source materials, including recycled deep portions of subducted oceanic lithosphere ("I" in Figure 7), but can also be enhanced by mixing with a melt-rich layer atop the LVZ ("II" in Figure 7) and by assimilation of earlier-formed metasomatic vein lithologies ("III" in Figure 7) in the oceanic lithosphere prior to eruption. A peridotite source ("I") is required, and ("II") and ("III") are not; however, the participation of the latter two can lead to extremely enriched OIB compositions (e.g., basanite and nephelinite melt).

2 Subducted ocean crust (SOC) is too depleted (i.e., $[\mathrm{La} / \mathrm{Sm}]_{\mathrm{N}}<1$ ) to act as a major source material for highly enriched OIB (e.g., $[\mathrm{La} / \mathrm{Sm}]_{\mathrm{N}} \gg>1$ ) (Figs. 1-3), which is not surprising because SOC, once entering the lower mantle, is too dense to rise back again to upper mantle depths (Figure 9). The revised ROC-model involving olivine-free pyroxenite as the source for Hawaiian OIB is apparently attractive, but has many problems. For example, this olivine-free pyroxenite, postulated to result from the interaction of SOC and harzburgite remains too depleted to explain the highly enriched geochemical signature of OIB.

3 Subducted continental sediments (CC) can be introduced into source regions of OIB, but there is no convincing evidence for their significance as a major enriched component in the global OIB source in terms of the familiar CC-like signatures. One possibility is that subducted continental sediments as well as subduction-eroded continental materials may have been largely mixed with and diluted by the ambient mantle with the otherwise distinct CC-like signatures lost before transported to OIB source regions.

4 The observation that OIB are not only enriched in incompatible elements, but also enriched in the progressively more incompatible elements with respect to major 
mantle minerals, and that OIB sources are, in general, more enriched than the primitive mantle requires that OIB source materials be pre-enriched by low- $F$ melt metasomatism. With all the possibilities considered, the interface (i.e., LAB) between the growing oceanic lithosphere and the top of the LVZ is the ideal site for mantle metasomatism, generating geochemically enriched deep portions of oceanic lithosphere. Globally, the 70 Myr history of oceanic lithosphere accretion to its full thickness of $90 \mathrm{~km}$ from the underlying LVZ records the history of mantle metasomatism. Similar mantle metasomatism may also take place at the base of the continental lithosphere. It is possible that partial melting may take place in the mantle transition zone, especially in the vicinity of the $410 \mathrm{~km}$ seismic discontinuity, but whether such melt, if formed at all, possesses the enriched geochemical characteristics as a metasomatic agent for OIB requires investigations.

5 The LVZ is compositionally layered. The reduction in seismic velocity at, or immediately below, the lithosphere-LVZ interface (i.e., $\mathrm{LAB}$ ) is attributed to an $\mathrm{H}_{2} \mathrm{O}-\mathrm{CO}_{2}$-rich silicate melt derived from within the LVZ. This melt is enriched in incompatible elements and migrates upwards, concentrating atop the LVZ. The deep portion of the LVZ thus becomes progressively more depleted and serves as the source for MORB.

6 In the subducted oceanic lithosphere, the SOC is very dense and will sink, contributing to the development of the LLSVPs at the base of the mantle, most prominently beneath the Pacific and Africa. The buoyant (relative to PREM) mantle part of the lithosphere (SML), which is $~ 15$ times the mass of the SOC, tends to "float", overlying the two global LLSVPs, explaining the surface geoid highs of the Pacific superswell and the elevated African continent and the associated dispersed volcanism.

7 The LLSVPs act as thermal insulators, which prevent the overlying SML from being heated and melted. However, at the edges of the LLSVPs, the SML material can be heated more directly by the outer core, and can melt. The low density of the SML (vs. PREM) and the even lower density of peridotite melts can cause the SML at the edges of the LLSVPs to form compositionally buoyant diapirs. These diapirs may become volumetrically significant and when they rise into the upper mantle, they will become significant melt sources, explaining why the eruption sites of major hotspot volcanoes and LIPs are associated with the edges, not interiors, of the LLSVPs.

8 We emphasize again that the major fertile OIB source material from depth (i.e., "I" in Figure 7) is likely SML, in particular the deep portions of metasomatic origin (Figure 7) because of their relative buoyancy and enriched geochemical characteristics; its bulk composition is peridotitic. On the other hand, subduction of the ocean crust is irreversible because of its high density; hence, there is little recycled SOC involved in the OIB petrogenesis (although tiny fragments of SOC could be entrained in some form of upwellings).

\section{Acknowledgements}

This is a sequel to Niu et al. (Journal of Petrology, Vol. 52, 14431468,2011 ) in honour of Peter J. Wyllie for his life-long dedication and significant scientific contributions to our better understanding how the Earth works by means of experimental petrology. Publication of this paper in Episodes also recognizes Peter's many years of scientific community services via IUGG and IUGS Offices. YN thanks
Pete for his friendship, encouragement and enjoyable scientific exchanges over the years, and for his profound influence in research philosophy. YN also thanks The Leverhulme Trust for a Research Fellowship, Durham University for a Christopherson/Knott Fellowship, China University of Geosciences in Beijing and Peking University for visiting Professorships in the preparation of the paper. This work is partially supported by the Chinese 111 Project (No B07011) and Chinese NSF (No 91014003, 41130314). Discussion with many colleagues over the years have been helpful, including Don Anderson, Rodey Batiza, Kevin Burke, Ian Campbell, Pat Castillo, David Clague, Geoff Davies, Henry Dick, Godfrey Fitton, Gillian Foulger, Fred Frey, Dave Green, Roger Hekinian, Claude Herzberg, Al Hofmann, Adrian Jones, Charlie Langmuir, Cin-Ty Lee, Shuguang Li, Caroline Lithgow-Bertelloni, Yan Liang, Bill McDonough, Jim Natland, Sebastian Pilet, Dean Presnall, Marcel Regelous, Vincent Salters, Norm Sleep, Alex Sobolev, Lars Stixrude, Ed Stolper, Bill White, Peter Wyllie, Yi-gang Xu and Youxue Zhang. We thank Ian Campbell, Keith Putirka, Vincent Salters and Sebastian Pilet for constructive comments that have helped improve the paper.

\section{References}

Agee, C.B., 1988, Crystal-liquid density inversions in terrestrial and lunar magmas: Physics of the Earth and Planetary Interiors, v. 107, pp. 63-74.

Anderson, D.L., and Spetzler, H., 1970, Partial melting and the low-velocity zone: Physics of the Earth and Planetary Interiors, v. 4, pp. 62-64.

Anderson, D.L., 2007, New Theory of the Earth. Cambridge University Press, 384pp.

Armstrong, R.L., 1968, A model for the evolution of strontium and lead isotopes in a dynamic Earth: Review of Geophysics, v. 6, pp. 175-200.

Baker, M.B., and Wyllie, P.J., 1992, High-pressure apatite solubility in carbonate-rich liquids: implications for mantle metasomatism: Geochimica et Cosmochimica Acta, v. 56, pp. 3409-3422.

Batiza, R., 1982, Abundances, distribution and sizes of volcanoes in the Pacific-Ocean and implications for the origin of non-hotspot volcanoes: Earth and Planetary Science Letters, v. 60, pp. 195-206.

Batiza, R., and Vanko, D.A., 1984, Petrology of young Pacific seamounts: Journal of Geophysical Research, v. 89, pp. 11235-11260.

Batiza, R., Smith, T.L., and Niu, Y.L., 1989, Geological and petrologic evolution of seamounts near the epr based on submersible and camera study: Marine Geophysical Researches, v. 11, pp. 169-236.

Becker, T.W., and Boschi, L., 2002, A comparison of tomographic and geodynamic mantle models: Geochemistry, Geophysics, and Geosystems, v. 3, 2001GC000168.

Birch, F., 1952, Elasticity and constitution of the earth interior: Journal of Geophysical Research, v. 57, pp. 227-286.

Brey, G.P., Bulatov, V.K., Girnis, A.V., and Lahaye, Y., 2008, Experimental melting of carbonated peridotite at 6-10 GPa: Journal of Petrology, v. 49, pp. 797-821.

Burke, K., and Torsvik, T.H., 2004, Derivation of Large Igneous Provinces of the past 200 million years from long-term heterogeneities in the deep mantle: Earth and Planetary Science Letters, v. 227, pp. 531- 538.

Burke, K., Steinberger, B., Torsvik, T.H., and Smethurst, M.A., 2008, Plume Generation Zones at the margins of Large Low Shear Velocity Provinces on the core-mantle boundary: Earth and Planetary Science Letters, v. 265, pp. 49-60.

Campbell, I.H., 2005, Large igneous provinces and the mantle plume hypothesis: Element, v. 1, pp. 265-270.

Campbell, I.H. \& Davies, G.F., 2006, Do mantle plumes exist? Episodes, v. 29, pp. 162-168.

Castillo, P.C., 1988, The DUPAL anomaly as a trace of the upwelling lower mantle: Nature, v. 336, pp. 667-670.

Castillo, P.R., Clague, D.A., Davis, A.S., and Lonsdale, P.F., 2010, Petrogenesis of Davidson Seamount lavas and its implications for fossil spreading center and intraplate magmatism in the eastern Pacific, Geochemistry Geophysics Geosystem, v 11, doi:10.1029/2009GC002992.

Chauvel, C., Hofmann, A.W., and Vidal, P., 1992, HIMU EM - The French 
Polynesian Connection: Earth and Planetary Science Letters, v. 110, pp. 99-119.

Christensen, U.R., and Hofmann, A.W., 1994, Segregation of subducted oceanic crust in the convecting mantle: Journal of Geophysical Research, v. 99 , pp. $19867-19884$.

Clift, P., and Vannucchi, P., 2004, Controls on tectonic accretion versus erosion in subduction zones: implications for the origin and recycling of the continental crust: Review of Geophysics, v. 42, RG2001. doi:10.1029/ 2003RG000127.

Coltorti, M., Bonadiman, C., Hinton, R.W., Siena, F., and Upton, B.G.J., 1999, Carbinatite metasomatism of the oceanic upper mantle: Evidence from clinopyroxenes and glasses from ultramafic xenoliths of Grade Comore, Indian Ocean: Journal of Petrology, v. 40, pp. 133-165.

Coltorti, M., and Gregoire, G. (eds.), 2008, Metasomatism in oceanic and continental lithospheric mantle: Geological Society Special Publication, v. 293, 361pp.

Danyushevsky, L.V., Leslie, R.A.J., Crawford, A.J., and Durance, P. , 2004, Melt inclusions in primitive olivine phenocrysts: The role of localized reaction processes in the origin of anomalous compositions: Journal of Petrology, v. 45, pp. 2531-2553.

Dasgupta, R., Hirschmann, M.M., and Smith, N.D., 2007, Partial melting experiments of peridotite $+\mathrm{CO}_{2}$ at $3 \mathrm{GPa}$ and genesis of alkalic ocean island basalts: Journal of Petrology, v. 48, pp. 2093-2124.

Davies, G.F., 2005, A case for mantle plumes: Chinese Science Bulletin, v. 50, pp. 1541-1554.

Donnelly, K.E., Goldstein, S.L., Langmuir, C.H., and Spiegelman, M., 2004, Origin of enriched ocean ridge basalts and implications for mantle dynamics: Earth and Planetary Science Letters, v. 226, pp. 347-366.

Dziewonski, A.M., 1984, Mapping the lower mantle - determination of lateral heterogeneity in P-velocity up to degree and order-6: Journal of Geophysical Research, v. 89, pp. 5929-5942.

Dziewonski, A.M., and Anderson, D.L., 1981, Preliminary reference Earth model: Physics of the Earth and Planetary Interiors, v. 25, pp. 297356.

Elliott, T., 2003, Tracers of the slab: Geophysical Monograph, v. 238, pp. 23-45.

Elliott, T., Plank, T., Zindler, A., White, W., and Bourdon, B., 1997, Element transport from slab to volcanic front at the Mariana arc: Journal of Geophysical Research, v. 102, pp. 14991-15019.

Foulger, G.R., 2005, Mantle plumes: Why the current skepticism? Chinese Science Bulletin, v. 50, pp. 1555-1560.

Foulger, G.R., Natland, J.H., Presnall, D.C. \& Anderson, D.L. (eds), 2005, Plates, Plumes, and Paradigms: Geological Society of America Special Papers, v. 388, 881 pp.

Ford, S.R., Garnero, E.J., and McNamara, A.K., 2006, A strong lateral shear velocity gradient and anisotropy heterogeneity in the lowermost mantle beneath the southern Pacific: Journal of Geophysical Research, v. 111, B03306, doi:10.1029/2004JB003574.

Frey, F.A., 1980, The origin of pyroxenites and garnet pyroxenites from Salt Lake Crater, Oahu, Hawaii, trace element evidence: American Journal of Science, v. 280A, pp. 427-499.

Frey, F.A., and Green, D.H., 1974, The mineralogy, geochemistry, and origin of lherzolite: Geochimica et Cosmochimica Acta, v. 38, pp. 1023-1059.

Frey, F.A., Green, D.H., and Roy, S.D., 1978, Integrated models of basalt petrogenesis: a study of quartz tholeiites to olivine melilitites from South eastern Australia utilizing geochemical and experimental petrological data: Journal of Petrology 19, 463-513, 1978.

Frey, F.A., Suen, C.J., and Stockman, H., 1985, The Ronda high temperature peridotite: Geochemistry and petrogenesis: Geochimica Cosmochimica Acta, v. 49, pp. 2469-2491.

Frost, D.J., 1999, The stability of dense hydrous magnesium silicates in earth's transition zone and lower mantle: Geochemical Society Special Publication, v. 6, pp. 283-297.

Garnero, E.J., Revenaugh, J., Williams, Q., Lay, T., and Kellogg, L.H., 1998, Ultralow velocity zone at the core-mantle boundary: American Geophysical Union Geodynamics Series, v. 28, pp. 319-334.

Garnero, E.J., Lay, T., and McNamara, A., 2007, Implications of lower mantle structural heterogeneity for existence and nature of whole mantle plumes. In Plates, plumes, and planetary processes: edited by Foulger, G., and Jurdy, D. Geological Society of America Special Paper, v. 430, pp. 79102.

Gast, P.W., 1968, Trace element fractionation and the origin of tholeiitic and alkaline magma types: Geochimimica et Cosmochimica Acta, v. 32, pp. 1055-1086

Grand, S.P., van der Hilst, R.D., and Widiyantoro, S., 1997, Global seismic tomography: A snapshot of convection in the Earth: GSA Today, v. 7, pp. 1-7.

Green, D.H., 1971, Composition of basaltic magmas as indicators of conditions of origin: Application to oceanic volcanism: Philosophical Transaction of the Royal Society of London, v. A268, pp. 707-725.

Green, D.H., 1991, The Earth's lithosphere and asthenosphere - Concepts and constraints derived from petrology and high pressure experiments: Special Publication of the Geological Society of Australia 17, 1-22.

Green, D.H., and Falloon, T.J., 2005, Primary magmas at mid-ocean ridges, 'hotspots,' and other intraplate settings: Constraints on mantle potential temperature. In: Foulger, G.R., Natland, J.H., Presnall, D.C., and Anderson, D.L. (eds) Plates, Plumes, and Paradigms. Geological Society of America Special Papers, v.388, pp. 217-248.

Green, D.H., Hibberson, W.O., Kovacs, I., and Rosenthal, A., 2010, Water and itsinfluence on the lithosphere-asthenosphere boundary: Nature, v. 467, pp. 448-451.

Green, D.H., and Liebermann, R.C., 1976, Phase equilibria and elastic properties of a Pyrolite model for the oceanic upper mantle: Tectonophysics, v. 32, pp. 61-92.

Gregoire, M., Moine, B.N., O'reilly, S.Y., Cottin, J.Y., and A. Giret, A., 2000, Trace element residence and partitioning in mantle xenoliths metasomatized by highly alkaline, silicate- and carbonate-rich melts (Kerguelen Islands, Indian Ocean: Journal of Petrology, v. 41, pp. 477509.

Halliday, A.N., Lee, D.-C., Tommasini, S., Davies, G.R., Paslick, C.R., Fitton, J.G., and James, D.E., 1995, Incompatible trace elements in OIB and MORB source enrichment in the sub-oceanic mantle: Earth and Planetary Science Letters, v. 133, pp. 379- 395 .

Hanan, B.B., and Graham, D.W., 1996, Lead and helium isotope evidence from oceanic basalts for a common deep source of mantle plumes: Science, v. 272, pp. 991-995.

Harmer, R.E., and Gittins, J., 1998, The case for primary, mantle-derived carbonatite magma: Journal of Petrology, v. 39, pp. 1895-1903.

Hart, S.R., 1984, A large-scale isotope anomaly in the southern-hemisphere mantle: Nature, v. 309, pp. 753-757.

Hart, S.R., Hauri, E.H., Oschmann, L.A., and Whitehead, J.A., 1992, Mantle plumes and entrainment: Isotopic evidence: Science, v. 256, pp. $517-$ 520

Harte, B., Hunter, R.H. and Kinny, P.D., 1993, Melt geometry, movement and crystallization, in relation to mantle dykes, veins and metasomatism: PhilosophicalTransaction of the Royal Society of London, Series A v. 342, pp. 1-21.

Hauri, E.H., Shimizu, N., Dieu, J.J., and Hart, S.R., 1993, Evidence for hotspot-related carbonatite metasomatism in the oceanic upper mantle: Nature, v. 365, pp. 221-227.

Helffrich, G.R., and Wood, B.J., 2001, The Earth's mantle: Nature, v. 412, pp. 501-507.

Hirano, N., Takahashi, E., Yamamoto, J., Abe, N., Ingle, S.P., Kaneoka, I., Hirata, T., Kimura, J-I., Ishi, T., Ogawa, Y., Machida, S, and Suyehiro, K., 2006, Volcanism in response to plate flexure: Science, v. 313, pp. 1426-1428.

Hirose, K., Takafuji, N., Sata, N., and Ohishi, Y., 2005, Phase transition and density of subducted MORB crust in the lower mantle: Earth and Planetary Science Letters 237, 239-251.

Hirose, K., and Lay, T., 2008, Discovery of post-perovskite and new views on the core-mantle boundary region: Elements, v. 4, pp. 183-189.

Hirschmann, M.M., and Stolper, E.M., 1996, A possible role for garnet pyroxenite in the origin of the 'garnet signature' in MORB: Contributions to Mineralogy and Petrology, v. 124, pp. 185-208.

Hirth, G., and Kohlstedt, D.L., 1995, Experimental Constraints on the dynamics of the partially molten upper-mantle - deformation in the diffusion creep Regime: Journal of Geophysical Research, v. 100, pp. 1981-2001.

Hofmann, A.W., 1988, Chemical differentiation of the Earth: the relationship between mantle, continental crust, and oceanic crust: Earth and Planetary Science Letters, v. 90, pp. 297-314.

Hofmann, A.W., 1997, Mantle geochemistry: The message from oceanic volcanism: Nature, v. 385, pp. 219-229. 
Hofmann, A.W., and Hart, S.R., 1978, An assessment of local and regional isotopic equilibrium in the mantle: Earth and Planetary Science Letters, v. 38 , pp. $44-62$.

Hofmann, A.W., and White, W.M. , 1982, Mantle plumes from ancient oceanic crust: Earth and Planetary Science Letters, v. 57, pp. 421-436.

Hou, Z., Tian, S., Yuan, Z., Xie, Yin, S., Yi, L., Fei, H., Yang, Z., 2006, The Himalayan collision zone carbonatites in western Sichuan, SW China: Petrogenesis, mantle source and tectonic implication: Earth and Planetary Science Letters, v. 244, pp. 234-250.

Humphreys, E.R., and Niu, Y.L., 2009, On the composition of ocean island basalts (OIB): The effects of lithospheric thickness variation and mantle metasomatism: Lithos, v. 112, pp. 118-136.

Ionov, D., 1998, Trace Element Composition of Mantle derived Carbonates and Coexisting Phasesin Peridotite Xenoliths from Alkali Basalts: Journal of Petrology, v. 39, pp. 1931-1941.

Jackson, M.G., Hart, S.R., Koppers, A.A.P., Staudigel, H., Konter, J., Blusztajn, J., Kurz, M., and Russell, M.A., 2007, The return of subducted continental crust in Samoan lavas: Nature, v. 448, pp. 684-687.

Jacobsen, S.D., Jiang, F., Mao, Z. Duffy, T.S., and Smyth, J.R., 2008, Effects of hydration on the elastic properties of olivine: Geophysical Research Letters, v. 35, doi:10.1029/2008GL034398.

Karason, H.,, and Van der Hilst, R.D., 2000, Constraints on mantle convection from seismic tomography: In: The History and Dynamics of Global Plate Motion, edited by Richards, M. R., Gordon, R., and Van der Hilst, R. D., American Geophysical Union Geophysical Monograph, v. 121, 277288.

Karato, S., and Jung, H., 1998, Water, partial melting and the origin of the seismic low velocity and high attenuation zone in the upper mantle: Earth and Planetary Science Letters, v. 157, pp. 193-207.

Kawakatsu, H., Kumar, P., Takei, Y., Shinohara, M., Kanazawa, T., Araki, E., and Suyehiro, K., 2009, Seismic evidence for sharp lithosphereasthenosphere boundaries of oceanic plates: Science, v. 324, pp. 449502 .

Kellogg, L.H., Hager, B.H., and van der Hilst, R.D., 1999, Compositional stratification in the deep mantle: Science, v. 283, pp. 1881-1884.

Keppler, H., Wiedenbeck, M., and Shcheka, S., 2003, Carbon solubility in olivine and the mode of carbon storage in the Earth's mantle: Nature, v. 424 , pp. 414-416.

Lambert, I.B., and Wyllie, P.J., 1968, Stability of hornblende and a model for the low velocity zone: Nature, v. 219, pp. 1240-1241.

Lambert, I.B., and Wyllie, P.J., 1970, Low-velocity zone of the Earth's mantle - incipient melting caused by water: Science, v. 169, pp.764-766.

Lassak, T.M., McNamara, A.K., Garnero, E.J., and Zhong, S., 2010, Coremantle boundary topography as a possible constraint on lower mantle chemistry and dynamics: Earth and Planetary Science Letters, v. 289, pp. 232-241

Li, C., Ripley, E. M., Tao, Y., and Mathez, E. A., 2008, Cr-spinel/olivine and Cr-spinel/liquid nickel partition coefficients from natural samples: Geochimica et Cosmochimica Acta, v. 72, pp. 1678-1684.

Li, C., and Ripley, M., 2010, The relative effects of composition and temperature on olivine-liquid Ni partitioning: Statistical deconvolution and implications for petrologic modelling: Chemical Geology, v. 275, pp. 99-104.

Li, L., Brodholt, J., and Alfe, D., 2009, Structure and elasticity of hydrous ringwoodite: A first principle investigation: Physics of the Earth and Planetary Interiors, v. 177, pp. 103-115.

Litasov, K., Eiji Ohtani, E., Langenhorst, F., Yurimoto, H., Kubo, T., and Kondo, T., 2003, Water solubility in Mg-perovskites and water storage capacity in the lower mantle: Earth and Planetary Science Letters, v. 211, pp. 189-203.

Lorinczi, P., and Houseman, G.A., 2009, Lithospheric gravitational instability beneath the Southeast Carpathians: Tectonophysics, v. 474, pp. 322-336.

Lloyd, F.E., and Bailey, D.K., 1975, Light element metasomatism of the continental mantle: the evidence and the consequences: Physics and Chemistry of the Earth, v. 9, pp. 389-416.

Mahoney, J.J., Sinton, J.M., Kurz, D.M., Macdougall, J.D., Spencer, K.J., and Lugmair, G.W., 1994, Isotope and trace element characteristics of a super-fast spreading ridge: East Pacific Rise, $13-23^{\circ} \mathrm{S}$ : Earth and Planetary Science Letters, v. 121, pp. 173-193.

Mahoney, J.J., Jones, W.B., Frey, F.A., Salters, V.J.M., Pyle, D.G., and Davies, H.L., 1995, Geochemical characteristics of lavas from Broken Ridge, the Naturaliste Plateau and southernmost Kerguelen Plateau: Oceanic plateau volcanism in the southeast Indian Ocean: Chemical Geology, v. 120 , pp. $315-345$.

Mao, Z., Jacobsen, S.D., Jiang, F., Smyth, J.R. Holl, C.M., and Duffy, T.S., 2008a, Elasticity of hydrous wadsleyite to $12 \mathrm{GPa}$ : Implications for Earth's transition zone: Geophysical Research Letters, v. 35, L21305, DOI: 10.1029/2008GL035618.

Mao, Z., Jacobsen, S.D., Jiang, F.M., Smyth, J.R., Holl, C.M., Frost, D.J., and Duffy, T.S., 2008b, Single-crystal elasticity of wadsleyites, $\beta$ $\mathrm{Mg}_{2} \mathrm{SiO}_{4}$, containing 0.37-1.66 wt.\% $\mathrm{H}_{2} \mathrm{O}$ : Earth and Planetary Science Letters, v. 268, pp. 540-549.

Matzen, A.K., Baker, M.B., Beckett, J.R., and Stolper, E.M., 2009, The temperature and pressure dependence of Ni partitioning between olivine and $\mathrm{MgO}$-rich silicate melt: Geochimica et Cosmochimica Acta, v. 73, pp. A851-A851.

McKenzie, D., and O'Nions, R.K., 1995, The source regions of oceanic island basalts: Journal of Petrology, v. 36, pp. 133-159.

McNamara, A.K., and Zhong, S., 2004, Thermochemical structures within a spherical mantle: Superplumes or piles?: Journal of Geophysical Research, v. 109, doi:10.1029/2003JB002847.

McNutt, M.K., 1988, Superswells: Reviews of Geophysics, v. 36, pp. 211244.

Mégnin, C., and Romanowicz, B., 2000, The shear velocity structure of the mantle from the inversion of body, surface, and higher modes waveforms: Geophysical Journal International, v. 143, pp. 709-728.

Nielson, J.E., and Noller, J.S., 1987, Processes of mantle metasomatism; Constraints from observations of composite peridotite xenoliths. In: Morris, E.M., and Pasteris, J.D. (eds) Mantle Metasomatism and Alkaline Magmatism: Geological Society of America Special Papers, v. 215, pp. 61-76

Nielson, J.E., and Wilshire, H.G., 1993, Magma transport and metasomatism in the mantle: A critical review of current geochemical models: American Mineralogist, v. 78, pp. 1117-1134

Nielson, J.E., Budahn, J.R., Unruh, D.M., and Wilshire, H.G.,1993, Actualistic models of mantle metasomatism documented in a composite xenolith from Dish Hill, California: Geochimica et Cosmochimica Acta, v. 57, pp. 105-121.

Menzies, M., and Murthy, V.R., 1980, Mantle metasomatism as a precursor to the genesis of alkaline magmas - isotopic evidence: American Journal of Science, v. 280A, pp. 622-638.

Menzies, M.A., 1983, Mantle ultramafic xenoliths in alkaline magmas: Evidence for mantle heterogeneity modified by magmatic activity. In: Continental Basalts and Mantle xenoliths edited by Hawkesworth, C.J., Norry, M.J., Shiva, Nantwich, pp. 92-110.

Menzies, M.A., Hawkesworth, C.J. (eds), 1987, Mantle Metasomatism: Academic Press, London, Geology Series.

Mierdel, K., Keppler, H., Smyth, J.R., Langenhorst, F., 2007, Water Solubility in aluminous orthopyroxene and the origin of Earth's asthenosphere: Science, v. 315, pp. 364-368.

Morgan, W. J., 1971, Convection plumes in the lower mantle: Nature, v. 230, pp. $42-43$

Morgan, W.J., 1972, Plate motions and deep mantle convection: Geological Society of America Memoir, v. 132, pp. 7-22

Newmann, E.R., Griffin, W.L., Pearson, N.J., and O'Reilly, S.Y., 2004, The evolution of the upper mantle beneath the Canary Islands: Information from trace elements and $\mathrm{Sr}$ isotope ratios in minerals in mantle xenoliths: Journal of Petrology, v. 45, pp. 2573-2612.

Ni, S., Tan, E., Gurnis, M., and Helmberger, D.V., 2002, Sharp sides to the African superplume: Science, v. 296, pp. 1850-1852.

Ni, S., and Helmberger, D.V., 2003, Seismological constraints on the South African superplume; could be the oldest distinct structure on Earth: Earth and Planetary Science Letters, v. 206, pp. 119-131.

Niu, Y.L., 1997, Mantle melting and melt extraction processes beneath ocean ridges: Evidence from abyssal peridotites: Journal of Petrology, v. 38, pp. 1047-1074.

Niu, Y.L., 2004, Bulk rock major and trace element compositions of abyssal peridotites: Implications for mantle melting, melt extraction and post, melting processes beneath ocean ridges: Journal of Petrology, v. 45, pp. 2423-2458.

Niu, Y.L., 2005, On the great mantle plume debate: Chinese Science Bulletin, v. 50, pp. $1537-1540$.

Niu, Y.L., 2005, Generation and evolution of basaltic magmas: Some basic concepts and a hypothesis for the origin of the Mesozoic, Cenozoic 
volcanism in eastern China: Geological Journal of China Universities, v. 11, pp. 9-46.

Niu, Y.L., 2006, Continental lithospheric thinning results from hydration weakening, not "delamination": http://www.mantleplumes.org/ Hydration.html.

Niu, Y.L., 2008, The origin of alkaline lavas: Science, v. 320, pp. 883-884.

Niu, Y.L., 2009, Some basic concepts and problems on the petrogenesis of intra-plate ocean island basalts: Chinese Science Bulletin, v. 54, pp. 41484160.

Niu, Y.L., and Batiza, R., 1991a, In-situ densities of silicate melts and minerals as a function of temperature, pressure, and composition: Journal of Geology, v. 99, pp. 767-775.

Niu, Y.L., and Batiza, R., 1991b, DENSCAL: A program for calculating the densities of sili-cate melts and minerals as a function of temperature, pressure, and composition in magma generation environment: Computers and Geosciences, v. 17, pp. 679-687.

Niu, Y.L., and Batiza, R., 1997, Trace element evidence from seamounts for recycled oceanic crust in the eastern Pacific mantle: Earth and Planetary Science Letters, v. 148, pp. 471-483.

Niu, Y.L., Collerson, K.D., Batiza, R., Wendt, J.I., Regelous, M., 1999, The origin of E-Type MORB at ridges far from mantle plumes: The East Pacific Rise at $11^{\circ} 20^{\prime}$ : Journal of Geophysical Research, v. 104, pp. 70677087.

Niu, Y.L., Hékinian, R., 2004. Ridge suction drives plume-ridge interactions (Chapter 9). In Oceanic Hotspots, edited by Hékinian, R., Stoffers, P., and Cheminée, J.-L.. Springer Verlag, New York, pp. 285-307.

Niu, Y.L., and O'Hara, M.J., 2003, Origin of ocean island basalts: A new perspective from petrology, geochemistry and mineral physics considerations: Journal of Geophysical Research, v. 108, 2209, doi:10.1029/2002JB002048.

Niu, Y.L., and O'Hara, M.J., 2007, Varying Ni in OIB olivines: Product of process not source: Geochimica et Cosmochimica Acta, v. 71, pp. A721A721.

Niu, Y.L., and O'Hara, M.J., 2009, MORB mantle hosts the missing Eu (Sr, $\mathrm{Nb}$, Ta and $\mathrm{Ti}$ ) in the continental crust: New perspectives on crustal growth, crust-mantle differentiation and chemical structure of oceanic upper mantle: Lithos, v. 112, pp. 1-17.

Niu, Y.L., and O'Hara, M.J., Pearce, J.A. , 2003, Initiation of subduction zones as a consequence of lateral compositional buoyancy contrast within the lithosphere: A petrologic perspective: Journal of Petrology, v. 44, pp. 851-866.

Niu, Y.L., Regelous, M., Wendt, J. I., Batiza, R., and O’Hara, M.J., 2002, Geochemistry of near-EPR seamounts: Importance of source vs. process and the origin of enriched mantle component: Earth and Planetary Science Letters, v. 199, pp. 327-345.

Niu, Y.L., Waggoner, D.G., Sinton, J.M., Mahoney, J.J., 1996, Mantle source heterogeneity and melting processes beneath seafloor spreading centers: The East Pacific Rise, $18^{\circ}-19^{\circ} \mathrm{S}$ : Journal of Geophysical Research, v. 101, pp. 27711-27733.

Niu, Y.L., Wilson, M., Hymphreys, E.R., and O'Hara, M.J., 2011, The Origin of Intra-plate Ocean Island Basalts (OIB): The lid effect and its geodynamic implications: Journal of Petrology, v. 52, pp. 1443-1468.

Ohtani, E., and Maeda, M., 2001, Density of basaltic melt at high pressure and stability of the melt at the base aof the lower mantle: Earth and Planetary Science Letters, v. 193, pp. 69-75.

Ono, S., Ito, E., and Katsura, T., 2001, Mineralogy of subducted basaltic crust (MORB) from 25 to $37 \mathrm{GPa}$, and chemical heterogeneity of the lower mantle: Earth and Planetary Science Letters, v. 190, pp. 5763.

O'Reilly, Y.S., and Griffin, W.L., 1988, Mantle metasomatism beneath western Victoria, Australia: I, Metasomatic processes in Cr-diopside lherzolites: Geochimica et Cosmochimica Acta, v. 52, pp. 433-447.

Pilet, S., Hernandez, J., Sylvester, P., and Poujol, M., 2005, The metasomatic alternative for ocean island basalt chemical heterogeneity: Earth and Planetary Science Letters, v. 236, pp. 148-166.

Pilet, S., Baker, M.B., Stolper, E.M., 2008, Metasomatized lithosphere and the origin of alkaline lavas: Science, v. 320, pp. 916-919.

Pilet, S., Baker, M.B., Muntener, O., and Stolper, E.M., 2011, Monte Carlo Simulations of Metasomatic Enrichment in the Lithosphere and Implications for the Source of Alkaline Basalts: Journal of Petrology, v. 52, pp. $1415-1442$.

Plank, T., and Langmuir, C.H., 1998, The chemical compositions of subducting sediments and its consequences for the crust and mantle: Chemical Geology, v. 145, pp. 325-394.

Presnall, D.C., and Gudfinnsson, G.H., 2005, Carbonate-rich melts in the oceanic low-velocity zone and deep mantle. In: Foulger, G.R., Natland, J. H., Presnall, D. C., Anderson, D.L. (eds) Plates, Plumes, and Paradigms. Geological Society of America Special Papers, v. 388, pp. 207-216.

Presnall, D.C., and Gudfinnsson, G.H., 2008, The origin of the oceanic lithosphere: Journal of Petrology, v. 49, pp. 615-632.

Presnall, D.C., and Gudfinnsson, G.H., 2009, Hawaiian volcanism - Magmas from the seismic low-velocity zone: Geochimica et Cosmochimica Acta, v. 73, pp. A1051-A1051.

Presnall, D.C., and Gudfinnsson, G.H., 2011, Oceanic volcanism from the low-velocity zone - without mantle plumes: Journal of Petrology, v. 52, pp. 1533-1546.

Prytulak, J., and Elliott, T., 2007, TiO, enrichment in ocean island basalts: Earth Planetary Science Letters, v. 263, pp. 388-403.

Rapp, R.P., Irifune, T., Shimizu, N., Nishiyama, N., Norman, M.D., and Inoue, J., 2008, Subduction recycling of continental sediments and the origin of geochemically enriched reservoirs in the deep mantle: Earth and Planetary Science Letters, v. 271, pp. 14-23.

Ritsema, H.J., van Heijst, J.H., Woodhouse, J.H., 1999, Complex shear velocity structure beneath Africa and Iceland: Science, v. 286, pp. 1925- 1928.

Romanowicz, B., and Gung, Y., 2002, Superplumes from the core-mantle boundary to the lithosphere: Implications for heat flux: Science, v. 296, pp. $513-516$.

Rudnick, R.L., and Gao, S., 2003, Composition of the continental crust: Treatise on Geochemistry, v. 3, pp. 1-64.

Schleicher, H., Kramm, U., Pernicka, E., Schidlowski, M., Schmidt, F., Subramanian, V., Todt, W., and Viladkar, S.G., 1998, Enriched subcontinental upper mantle beneath southern India: Evidence from $\mathrm{Pb}$, $\mathrm{Nd}, \mathrm{Sr}$, and C-O isotope studies on Tamil Nadu carbonatites: Journal of Petrology, v. 39, pp. 1765-1785.

Sen, G., Keshav, S., and Bizimis, M., 2005, Hawaiian mantle xenoliths and magmas; Composition and thermal character of the lithosphere: American Mineralogist, v. 90, pp. 871-887.

Sobolev A.V., Hofmann, A.W., and Nikogosian, I.K., 2000, Recycled oceanic crust observed in "ghost plagioclase" within the source of Mauna Loa lavas: Nature, v. 404, pp. 986-990.

Sobolev, A.V., Hofmann, A.W., Sobolev, S.V., and Nikogosian, I.K., 2005, A olivine-free mantle source of Hawaii shield basalts: Nature, v. 434, pp. $590^{-} 597$.

Sobolev, A.V., and 19 others, 2007, The amount of recycled crust in sources of mantle-derived melts: Science, v. 316, pp. 412-417.

Song, S.G., Zhang, L.F., Niu, Y.L., Su, L., Song, B., and Liu,D. Y., 2006 , Evolution from oceanic subduction to continental collision: A case study from the Northern Tibetan Plateau based on geochemical and geochronological data: Journal of Petrology, v. 47, pp. 435-455.

Stern, R.J., 2007, When and how did plate tectonics begin? Theoretical and empirical considerations: Chinese Science Bulletin, v. 52, pp. 578-591.

Stolper, E.M., and Asimow, P.D., 2007, Insights into mantle melting from graphical analysis of one-component systems: American Journal Science, v. 307, pp. 1051-1139.

Su, W., and Dziewonski, A.M., 1997, Simultaneous inversion for 3-D variations in shear and bulk velocity in the mantle: Physics of the Earth and Planetary Interiors, v. 100, pp. 135- 156

Sun, S.-s., and Hanson, G.N., 1975, Origin of Ross Island basanitoids and limitations upon the heterogeneity of mantle sources for alkali basalts and nephelinites: Contributions to Mineralogy and Petrology, v. 52, pp. 77-106.

Sun, S.-s., and McDonough, W.F., 1989, Chemical and isotopic systematics in ocean basalt: Implication for mantle composition and processes. In Magmatism in the Ocean Basins edited by Saunders, A. D., Norry, M. J., Geological Society Special Publication, v. 42, pp. 313-345.

Takazawa, E., Frey, F.A., Shimizu, N., and Obata, M., 2000, Whole rock compositional variations in an upper mantle peridotite (Horoman, Hokkaido, Japan): Are they consistent with a partial melting process? Geochimica et Cosmochimica Acta, v. 64, pp. 695- 716.

Thorne, M., Garnero, E.J., and Grand, S., 2004, Geographic correlation between hot spots and deep mantle lateral shear-wave velocity gradients: Physics of Earth and Planetary Interiors, v. 146, pp. 47-63.

Toh, A., Romanowicz, B., Capdeville, Y., and Takeuchi, N., 2005, 3D effects of sharp boundaries at the borders of the African and Pacific Superplumes: 
observation and modeling: Earth and Planetary Science Letters, v. 233, pp. 137-153.

van der Hilst, R.D., Widiyantoro, S., and Engdahl, E.R., 1997, Evidence for deep mantle circulation from global tomography: Nature, v. 386, pp. 578-584.

von Huene, R., and Scholl, D.W., 1991, Observations at convergent margins concerning sediment subduction, subduction erosion, and the growth of continental crust: Review of Geophysics, v. 29, pp. 279-316.

Walter, M.J., 1998, Melting of Garnet Peridotite and the Origin of Komatiite and Depleted Lithosphere: Journal of Petrology, v. 39, pp. 29-60.

Walter, M.J., Bulanoa, G.P., Armstrong, L.S., Keshav, S., Blundy, J.D., Gudfinnsson, G., Lord, O.T., Lennie, A. R., Clark, S. M., Smith, C. B., and Gobbo, L., 2008, Primary carbonatite melt from deeply subducted oceanic crust: Nature, v. 454, pp. 622-626.

Wang, Y., and Wen, L., 2004, Mapping the geometry and geographic distribution of a very-low velocity province at the base of the Earth's mantle: Journal of Geophysical Research, v. 109, B10305, doi:10.1029/ $2003 J B 002674$.

Wang, Z.R., Gaetani, G.A., 2008, Partitioning of Ni between olivine and siliceous eclogite partial melt: experimental constraints on the mantle source of Hawaiian basalts: Contributions to Mineralogy and Petrology, v. 156 , pp. 661-678.

White, B.S., and Wyllie, P.J., 1992, Phase relations in synthetic lherzolite$\mathrm{H}_{2} \mathrm{O}-\mathrm{CO}_{2}$ from 20-30 kb, with applications to melting and metasomatism: Journal of Volcanology and Geothermal Research, v. 50, pp. 117-130.

White, W.M., 1985, Sources of oceanic basalts: radiogenic isotopic evidence: Geology, v. 13, pp. 115-118.

White, W.M., 2010, Ocean island basalts a.nd mantle plumes; The geochemical perspective: Annual Review of Earth and Planetary Sciences, v. 38, pp. 133-160.

White, W.M., and Duncan, R.A., 1996, Geochemistry and geochronology of the Society Islands: New evidence for deep mantle recycling: American Geophysical Union Geophysical Monograph, v. 95, pp. 183-206.

Willbold, M., and Stracke, A., 2006, Trace element composition of mantle end-members: Implications for recycling of oceanic and upper and lower continental crust: Geochemistry Geophysics Geosystems, v 7, doi: 10.1029/2005GC001005.

Williams, Q., Revenaugh, J., and Garnero, E., 1998, A correlation between ultra-low basal velocities in the mantle and hot spots: Science, v. 281, pp. 546-549.

Wilshire, H.G., 1987, A model of mantle metasomatism. In:Morris, E. M., and Pasteris, J. D. (eds) Mantle Metasomatism and Alkaline Magmatism: Geological Society of America Special Papers v. 215, pp. 47-60.

Wilson, M., Rosenbaum, J.M., and Dunworth, E.A., 1995, Melilitites: partial melts of the thermal boundary layer?: Contributions to Mineralogy and Petrology, v. 119, pp. 181-196.

Wilson, M., 1989, Igneous petrogenesis - A global tectonic approach, Kluwer Academic Publishers, London, 466 pp.

Workman, R.K., Hart, S.R., Jackson, M, Regelous, M., Farley, K. A., Blusztajn, J., Kurz, M., and Staudigel, H., 2004, Recycled metasomatised lithosphere as the origin of the enriched mantle II (EM2) end-member: Evidence from the Samoan Volcanic Chain: Geochemistry, Geophysics and Geosystems, v. 5, doi:10.1029/2003GC00623

Workman, R.K., and Hart, S.R., 2005, Major and trace element composition of depleted MORB mantle (DMM): Earth and Planetary Science Letters, v. 231 , pp. $53-72$.

Wyllie, P.J., 1971, Role of water in magma generation and initiation of diapiric uprise in the mantle: Journal of Geophysical Research, v. 76, pp. 13281338.

Wyllie, P.J., 1977, Peridotite- $\mathrm{CO}_{2}-\mathrm{H}_{2} \mathrm{O}$, and carbonatitic liquids in the upper asthenosphere. Nature, v. 266, pp. 45-47.

Wyllie, P.J.,, 1980, The origin of kimberlite. Journal of Geophysical Research, v. 85 , pp. $6902-6910$.

Wyllie, P.J., 1984, Conditions for melting and metasomatism in the earth's mantle. Proceedings of the 27th International Geological Congress, Moscow, v. 9, pp. 581-604. VNU Science Press, Utrecht.

Wyllie, P.J., 1985, Conditions for melting and metasomatism in the earth's mantle. Geologica Carpathica, v. 36, pp. 323-335.

Wyllie, P.J.,1987a, Discussion of recent papers on carbonated peridotite, bearing on mantle metasomatism and magmatism. Earth Planetary Science Letters, v. 82, pp. 391-397, 401-402.

Wyllie, P.J., 1987b, Transfer of subcratonic carbon into kimberlites and rare earth carbonatites. In Magmatic Processes: Physicochemical Principles edited by Mysen, B. O. The Geochemical Society Special Publication, v. 1, pp. 107-119

Wyllie, P.J.,, 1987c, Metasomatism and fluid generation in mantle xenoliths: experimental. In Mantle Xenoliths edited by Nixon, P. H., Wiley, New York, p. 609-621.

Wyllie, P.J.,, 1988a, Solidus curves, mantle plumes, and magma generation beneath Hawaii. Journal of Geophysical Research, v. 93, pp. 4171-4181.

Wyllie, P.J., 1988b, Magma genesis, plate tectonics, and chemical differentiation of the Earth. Reviews of Geophysics, v. 26, pp. 370404.

Wyllie, P.J., and Huang, W.L., 1975, Influence of mantle $\mathrm{CO}_{2}$ in the generation of carbonatites and kimberlites. Nature, v. 257, pp. 297-299.

Wyllie, P.J., and Huang, W.L., 1976, High $\mathrm{CO}_{2}$ solubilities in mantle magmas. Geology, v. 4, pp. 21-24.

Wyllie, P.J., Huang, W.-L., Otto, J., and Byrnes, A.P., 1983, Carbonation of peridotites and decarbonation of siliceous dolomites represented in the system $\mathrm{CaO}-\mathrm{MgO}-\mathrm{SiO}_{2}-\mathrm{CO}_{2}$ to $30 \mathrm{kbar}$. Tectonophysics, v. 100, pp. 359388.

Wyllie, P.J., and Lee, W.-J, 1998, Model system controls on conditions for formation of magnesiocarbonatite and calciocarbonatite magmas from the mantle. Journal of Petrology, v. 39, pp. 1885-1893.

Wyllie, P.J.,, and Sekine, T., 1982, The formation of mantle phlogopite in subduction zone hybridization. Contributions to Mineralogy and Petrology, v. 79, pp. 375-380.

Wyllie, P.J., and Ryabchikov, I.D., 2000, Volatile components, magmas, and critical fluids in upwelling mantle. Journal of Petrology, v 41, pp. 11951206.

Yaxley, G.M., Green, D.H., and Kamenetsky, V., 1998, Carbonatite metasomatism in southern Australia lithosphere. Journal of Petrology, v. 39, pp. 1917-1930.

Ye, Y., Schwering, R.A, and Smyth, J.R., 2009, Effects of hydration on thermal expansion of forsterite, wadsleyite, and ringwoodite at ambient pressure: American Mineralogist, v. 94, pp. 899-904.

Zindler, A., and Hart, S.R., 1986, Chemical geodynamics. Annual Review of Earth and Planetary Sciences, v. 14, pp. 493-571. 